\title{
Yeniden Yapılandırma Çalışmalarının Bankacılık Sektörünün Gelişimine Etkileri: Türkiye İncelemesi \\ (Effects of Restructuring Efforts to the Development of Banking Sector: Turkey Examination)
}

\section{Dr. Mustafa Tevfik KARTAL iD a}

a Borsa İstanbul Stratejik Planlama ve Yatırımcı İlişkileri Direktörlüğ̈̈̈, İstanbul, Türkiye. mustafatevfikkartal@gmail.com

\begin{tabular}{|c|c|}
\hline MAKALE BİLGİSİ & ÖZET \\
\hline Anahtar Kelimeler: & aşanan ağır bankacılık krizlerinin ardından bankacılık \\
\hline Bankacilık & yeniden yapılandırma programı başlatılmış ve bankacılık sektörü yapılandırılmaya tabi \\
\hline & nuştur. 2008 yılında yaşanan küresel kriz ise Türkiye için yeni bir zorluk dönemi oluşturmuş \\
\hline Genlşım & bu süreçte de yeni önlemler alınmıştır. Alınan her türlü tedbir sektör üzerinde olumlu veya \\
\hline Yapılandirma & olumsuz etkileri oluşturmaktadır. Bu nedenle, gerçekleştirilen yapılandırma çalışmalarının Türk \\
\hline Türk Bankacıllk Sektörü & $\begin{array}{l}\text { Bankacılık Sektörünün gelişimi üzerindeki yansımalarının ele alınması amacıyla bu çalışma } \\
\text { hazırlanmıştır. }\end{array}$ \\
\hline $\begin{array}{l}\text { Gönderilme Tarihi } 3 \text { Ağustos } \\
2019\end{array}$ & $\begin{array}{l}\text { Yöntem - Türkiye'de 2003-2019/10 döneminde seçilmiş makro göstergelere (toplam aktifler, } \\
\text { krediler, mevduatlar, net kar, yoğunlaşma) ve finansal sağlamlık göstergelerine (karlılık, sermaye } \\
\text { yeterliliği rasyosu (SYR), likidite, yabanc para net genel pozisyonu, takipteki krediler) ilişkin } \\
\text { veriler betimsel istatistik yöntemiyle incelenmiştir. }\end{array}$ \\
\hline Revizyon Tarihi 2 Aralık 2019 & Bulgular - İnceleme sonuçlarına göre, uygulanan yapılandırma programları ve bu kapsamda \\
\hline Kabul Tarihi 16 Aralık 2019 & $\begin{array}{l}\text { alınan tedbirler Türk bankacılık sektörünün gelişimi üzerinde genel olarak olumlu etki yapmıştır. } \\
\text { İncelenen makro göstergelerde ve finansal sağlamlık göstergelerinde 2003-2019/10 döneminde } \\
\text { kayda değer gelişme görülmüştür. Bununla birlikte, makro göstergelerden mevduatlarda } \\
\text { dolarizasyon yaşandığı belirlenmiştir. Diğer taraftan, finansal sağlamlık göstergelerinden yabanc1 } \\
\text { para net genel pozisyonu (YPNGP)/yasal özkaynak standart oranında \%20 olan yasal sınırın çok }\end{array}$ \\
\hline Makale Kategorisi: & üzerinde gelişmeler yaşandığı; takipteki kredilerin ise $\% 5,4$ oranına ulaştığı belirlenmiştir. \\
\hline Araştırma Makalesi & $\begin{array}{l}\text { Tartışma - Makro ve finansal sağlamlık göstergelerinde genel hatlarıyla olumlu gelişme } \\
\text { yaşanmasına karşın, son dönemlerde mevduatlarda dolarizasyon ve takipteki kredilerde artış } \\
\text { görülmektedir. Bu durum sektör açısından yeni zorluklar oluşturmaktadır. Bu nedenle, sektöre } \\
\text { yönelik yeni ve kapsamlı bir yapılandırma programı uygulanması zorunlu hale gelmiştir. } \\
\text { Mevduatlardaki dolarizasyon ve takipteki krediler yönetilemez boyuta ulaşmadan önce sektöre } \\
\text { yönelik kapsamlı bir yapılandırma programı süratle ve kararlılıkla uygulanmalıdır. }\end{array}$ \\
\hline
\end{tabular}

\begin{tabular}{|c|c|}
\hline ARTICLE INFO & ABSTRACT \\
\hline Keywords: & \multirow{6}{*}{$\begin{array}{l}\text { Purpose - Turkey started a banking sector restructuring program after severe banking crises seen } \\
2000 \text { and } 2001 \text { and banking sector was subjected to restructuring. The global financial crisis seen in } \\
2008 \text { created a new difficult era for Turkey and new measures were also taken in this process. All } \\
\text { measures taken have positive or negative effects on the sector. For this reason, this study is } \\
\text { prepared in order to address the effects of the structuring efforts carried out on the development of } \\
\text { the Turkish Banking Sector. }\end{array}$} \\
\hline Banking & \\
\hline & \\
\hline Development & \\
\hline Restructuring & \\
\hline Turkish Banking Sector & \\
\hline Turkey & $\begin{array}{l}\text { Design/methodology/approach - Data in Turkey for the period of 2003-2019/10 regarding macro } \\
\text { indicators (total assets, loans, deposits, net income, and concentration components), and financial } \\
\text { stability indicators (profitability capital adequacy ratio (CAR) net foreign currency position }\end{array}$ \\
\hline Received 3 August 2019 & liquidity, nonperforming loans components) are analyzed with the descriptive statistic method. \\
\hline Revised 2 December 2019 & \multirow{4}{*}{$\begin{array}{l}\text { Findings - According to the results of the examination, it is determined that the structuring efforts } \\
\text { carried out and measures taken have a positive effect generally on the development of the Turkish } \\
\text { banking sector. Macro and financial stability indicators examined have experienced remarkable } \\
\text { development for the period of in 2003-2019/10. However, dollarization has been observed in } \\
\text { deposits which are one of the macro indicators. On the other hand, net foreign currency position } \\
\text { (YPNGP)/legal equity standard ratio has been quite above the legal limit of } 20 \% \text {; and non- } \\
\text { performing loans reached } 5.4 \% \text { which are both the financial stability indicators. }\end{array}$} \\
\hline Accepted 16 December 2019 & \\
\hline Article Classification: & \\
\hline Research Article & \\
\hline
\end{tabular}

Discussion - Although a significant development has been in macro and financial stability 
indicators, there has been a dollarization trend in deposits and there is an increase in nonperforming loans in recent times. This situation creates new difficulties for the sector. For this reason, it has become compulsory to start new and comprehensive restructuring program intended for the sector. A comprehensive restructuring program for the sector should be carried out rapidly and decisively before dollarization in deposits and nonperforming loans reach an unmanageable level.

\section{Giriş}

Küreselleşmenin hız kazanması ile birlikte ülke ekonomileri daha dışa açık ve dolayısıyla birbirine daha fazla bağımlı hale gelmiştir. Bu etkinin en fazla hissedildiği alanların başında ise finansal piyasalar gelmektedir. Sermaye akımlarının uluslararası nitelik kazanmasıyla birlikte, finansal piyasalar yabancı sermayeye oldukça duyarlı hale gelmiştir. Bu kapsamda, özellikle 1980 sonrası süreçte ülkeler daha fazla yabancı sermaye çekebilmek için finansal piyasalar başta olmak üzere birçok alanda serbestleşme süreçleri başlatmıştır. Türkiye'de de 1980 yılında 24 Ocak kararları ile başlayan bu süreç, diğer düzenlemelerle devam etmiştir.

Finansal serbestleşme sürecinin peyderpey gerçekleştirilmesi oldukça önemlidir. Makroekonomik göstergelerde gerekli istikrar sağlanmadan başlatılan serbestleşme, finansal kriz ihtimalini artırmaktadır. Bankacılık sektöründe düzenleme ve denetim sistemlerinin etkin çalışmaması, aşırı risk almayı önleyen düzenlemelerin bulunmaması, banka bilançolarının bozulmasına yol açmaktadır (Mishkin, 1999: 1530). Nitekim 1980 sonrası gelişmekte olan ülkelerde görülen finansal krizlerin birçoğu sermaye akımlarının serbestleştirilmesi ve buna bağlı olarak döviz kurlarındaki aşırı bozulmadan kaynaklanmıştır (Arı ve Dağtekin, 2008: 192). Bunun temelinde ise gerekli altyapı oluşturulmadan başlatılan finansal serbestleşme süreçlerinin ülkeleri ani sermaye akımlarına karşı savunmasız bırakması yatmaktadır.

Finansal serbestleşme sürecinde Türkiye ele alındığında, 1994, 1998, 1999, 2000 ve 2001 krizlerinin yaşandığı görülmektedir. Diğer bir ifade ile Türkiye'nin başlattığı finansal serbestleşme maalesef başarılı bir şekilde tamamlanamamış, reformlar aşamalı ve koordineli bir şekilde gerçekleştirilmediğinden dolayı finansal sektörde artan kırılganlık ani ve hızlı sermaye çıkışı nedeniyle krizlerle sonuçlanmıştır (Kılcı, 2017: 57-58).

1999 krizinden sonra Türk Bankacıllk Sektörü (TBS)'nün düzenlemesi, denetlenmesi ve gözetimi hususlarındaki eksikliklerin giderilmesi için öncelikle 4389 sayılı Bankacılık Kanunu (BK) yayınlamış, müteakiben özerk bir kurum olarak Bankacılık Düzenleme ve Denetleme Kurumu (BDDK) oluşturulmuştur. Henüz yeni yapı tam olarak oturmamışken 2000 ve 2001 krizleri meydana gelmiştir. Başlatılan düzenleme ve yapılandırma çabalarının sonuca ulaşmaması ve kısmen olumsuz etki yapması, diğer krizlerden daha fazla tahribata yol açan 2000 ve 2001 krizlerinin yaşanmasına neden olmuştur. 2001 bankacilık krizi TBS'nin güvenli, sağlam ve sağlıklı bir yapısının olmadığını göstermiştir (İslatince, 2018: 156). Böylece, TBS'nin yeniden yapılandırılmasına yönelik çalışmalar için yeni bir milat olmuştur.

Türkiye'de yaşanan krizler, kamu kesiminin ve reel sektörün yanı sıra başta TBS olmak üzere finansal kesimin yapılandırılmasını gerekli ve elzem kılmıştır. Bu kapsamda, Şubat 2001 krizini müteakiben Nisan ayında Güçlü Ekonomiye Geçiş Programı ilan edilmiş, Mayıs ayında ise Bankacılık Sektörü Yeniden Yapılandırma Programı (BSYYP) programı açıklanmıştır (Bumin, 2016: 178). TBS için BSYYP dönüm noktalarından biri olmuştur (Çam ve Özer, 2018: 337). Yapılandırma çalışmaları kapsamında 2005 yılında 5411 sayılı BK yayınlanırken BDDK'nın ikincil düzenleme yapma yetkisi aynen korunmuştur (BK, 2005: madde 88).

BK'nın verdiği yetkiye istinaden BDDK tarafından çok sayıda düzenleme yürürlüğe konulmuştur. Bu kapsamda, BDDK tarafından kurumsal yönetim ilkeleri, izne tabi işlemler, iradi tasfiye, özkaynaklar, kredi işlemleri, mevduat ve katılım fonu, sermaye ve likidite yeterliliği, muhasebe uygulamaları, iç sistemler, bağımsız denetim, destek, derecelendirme ve değerleme hizmetleri gibi temel hususlar hakkında düzenlemeler 2006 yılında yapılmıştır. 2006 yılından sonra, BDDK tarafından Basel III'e uyum kapsamında 2013, 2014 ve 2015 yıllarında birçok rehber ve yönetmelik yayınlanmıştır (Kartal, 2017: 171). Ayrıca, Basel komitesi tarafından Türk bankacilık mevzuatının Basel'e uyum seviyesinin belirlenmesi çalışması yoğun düzenlemelerin yapıldığı bir diğer dönem olmuştur. Bu kapsamda, 2015 ve 2016 yıllarında BDDK tarafından birçok rehber ve yönetmelikte güncelleme yapılmıştır. 
BSYYP, TBS'de bir konsolidasyon sürecini başlatmış, bunun sonucunda oyuncu sayısından rekabet düzeyine kadar birçok hususta değişiklik yaşanmıştır. Böylece, TBS'nin aracılık işlevi ve araç çeşitliliği de artış göstermiştir (Coşkun vd., 2012: 1-2). Diğer taraftan, 2008 küresel krizi TBS açısından yeni bir zorluk dönemini başlatmıştır. 2001 krizinden ders çıkarılarak yapılandırma adımlarının süratle atılması bu krizin olumsuz etkilerini sınırlamıştır.

2018 yılında bozulmaya başlayan ulusal ve uluslararası makro ortamla birlikte TBS günümüzde yeni bir meydan okumayla karşı karşıyadır. Başta takipteki kredilerde artış, kredi büyümesinin yavaşlaması, mevduat tabanındaki daralma, kredi/mevduat oranının \%100'ün üzerinde olması gibi çeşitli göstergelerde görülen bozulmalar, TBS'yi yeni bir yapılandırma sürecine girmeye zorlamaktadır. Bu konuda farklı çabaların olduğu kamuoyuna yansımakla birlikte sektöre yönelik kapsamlı bir yapılandırma süreci halen başlatılmamıştır.

Yaşanan krizler ve yeniden yapılandırmaya yönelik alınan tedbirler sonrasında 2003-2019/10 döneminde TBS'nin gelişimini ele alan bu çalışma beş bölümden oluşmaktadır. İkinci bölümde, krizlere ve yeniden yapılandırma programlarına ilişkin kavramsal altyapı ele alınmıştır. Üçüncü bölümde, bankacılık sektörünün yapılandırılması ile ilgili literatürde yer alan bazı çalışmalar incelenmiştir. TBS'nin gelişiminin incelendiği dördüncü bölümde, yapılandırma çalışmalarının TBS'nin gelişimi üzerindeki etkileri perspektifinden 2003-2019/10 döneminde makro göstergelerin (toplam aktifler, krediler, mevduatlar, net kar, yoğunlaşma) ve finansal sağlamlık göstergelerinin (karlılık, SYR, likidite, yabancı para net genel pozisyonu, takipteki krediler) gelişimi ele alınmıştır. Son bölümde değerlendirme yapılmış ve önümüzdeki döneme ilişkin beklentilere yer verilmiştir.

\section{Kavramsal Altyap1}

Bu bölümde, genel hatları ile 2000 ve sonrasında Türkiye'yi etkileyen krizler ve ardından yeniden yapılandırma programları ele alınmıştır.

\subsection{Türkiye'yi Etkileyen Ulusal ve Uluslararası Krizler}

1980 sonrasında finansal serbestleşme süreciyle birlikte gelişmekte olan ülkelerde birçok krizler yaşanmıştır. Türkiye açısından 2000 ve sonrasında yaşanan 3 önemli kriz olup bunlar Kasım ayında ortaya çıan 2000, Şubat ayında ortaya çıkan 2001 ve son çeyrekte ortaya çıkan 2008 küresel krizleridir (Çolak, 2001: 20).

Kasım 2000 krizi, temel olarak likidite sıkışıklığına bağlı döviz talebindeki artış şeklinde ortaya çıkmıştır. Uluslararası piyasalardaki bozulma ve ülkede yaşanan olumsuz gelişmeler ise kriz ortamını desteklemiştir. Krizin durdurulmasında IMF kredisi faydalı olurken enflasyonu düşürme programı ise sekteye uğramıştır. Bu süreçte Tasarruf Mevduatı Sigorta Fonu (TMSF) bünyesine alınan bankalar ile TCMB'nin kriz sürecindeki davranış tarzı önemli rol oynamıştır (Yıldırım, 2004: 10-11).

Şubat 2001 krizi ise finansal piyasalardaki kırılganlıklar sonucu ortaya çıkmıştır (Yıldırım, 2004: 9). Makroekonomideki istikrarsızlık, yüksek kamu kesimi açıkları, risk yönetiminin zayıflığı, kamu bankalarının sistemi bozucu etkisi gibi faktörler TBS'de bozulmaya; küçük ölçekli ve parçalı bankacılık yapısı, kamu bankalarının yüksek sektör payı, düşük aktif kalitesi, bankaların özkaynak yetersizliği, yetersiz iç kontrol, risk yönetimi ve kurumsal yönetim yapısı, piyasa risklerine aşırı duyarlılık gibi faktörler ise TBS'nin krizde öncü rol oynamasına neden olmuştur (Çolak, 2012: 6). Ayrıca, 2001 Şubat ayında dalgalı kur sistemine geçilmiştir (Serdengeçti 2001: 14). Şubat 2001 krizi TL'nin değerinde \%90 seviyesinde değer kaybına neden olurken bu durum TMSF bünyesindeki bankaların değerini düşürerek krizin ülkeye olan maliyetini önemli miktarda artırmıştır (Altay, 2002 78-79).

Temel olarak 2000 ve 2001 krizleri piyasanın likidite ihtiyacından oluşan atakların yarattı̆̆ı döviz talebinin genişlemesiyle oluşmuştur (Tunç, 2001: 20). Bu krizler sonrasında birçok bankanın TMSF'ye devredilmesi TBS'de sıkıntılı bir dönemin yaşanmasına neden olmuştur (Yıldırım, 2004: 13-14). 1997-1999 arasında TMSF'ye devredilen 8 bankaya, 2000 ve 2001 krizlerindeki 12 banka eklendiğinde 2001 sonu itibarıla fona devredilen banka sayısı 20 olmuştur (TMSF, 2019). Bu devirlerin bir sonucu olarak, 2000 sonunda 79 olan banka sayısı 2001 sonunda 67'ye ve 2002 sonunda 59'a gerilemiştir (Arabac1, 2018: 35). Uygulanan BSYYP kapsamında birleşme ve devir almaların da devam etmesiyle banka sayısı 2003 sonunda 55'e, 2008 yılında 
ise 49'a gerilemiş, ancak 2015 yılı ile birlikte banka sayısı 50 seviyesinin üzerine çıkarak 52'ye ulaşmıştır (Arabac1, 2018: 37).

2008 küresel krizi ise esasında kullandırılan konut kredisi (mortgage) teminatlı kredilerin menkulleştirilmesine dayalı olarak Amerika Birleşik Devletleri'nde çıkmıştır. Emlak fiyatlarındaki artış eğilimine istinaden değişken faizle kullandırılan bu krediler, faiz artışları nedeniyle ödenemez hale gelince Lehman Brothers gibi bilançolarında çok sayıda bu kredilerden tutan finansal kuruluşlarda çöküş süreci başlamış, sonrasında bu süreç tüm dünyayı etkisi altına almıştır (İslatince, 2018: 162). Diğer taraftan, söz konusu finansal araçların TBS'deki banka bilançolarında bulunmaması sayesinde 2008 krizinin etkileri diğer ülkelere kıyasla Türkiye'de daha sınırlı seviyede hissedilmiştir.

\subsection{Yeniden Yapılandırma Programları}

Yeniden yapılandırma programlarının uygulanabilmesi için öncelikle makroekonomik istikrarın sağlanmasını hedefleyen altyapı oluşturulmalıdır. Ardından bankaların yapılandırılmasını içeren finansal yeniden yapılandırma uygulanmalıdır. Devamında şirketlerin yapılandırılmasını içeren kurumsal yapılandırma aşamasına geçilmektedir. Son olaraksa devletin yeniden yapılandırma sürecindeki sorumluluğunun azaltılması gerçekleştirilmektedir (Ataman Erdönmez, 2002: 68).

Yeniden yapılandırmada bankaların finansal yapılarının iyileştirilmesi veya özkaynaklarının kısa sürede artırılması şeklinde iki temel yaklaşım bulunmaktadır. Birinci yaklaşımda, bankaların finansal yapılarının belirli bir dönemde güçlendirilmesine ve bunun için bankaların karlılığını artıracak bir makroekonomik ortam oluşturulmasına çalışılmaktadır. İkinci yaklaşımda ise özkaynakların kısa bir süre içinde artırılması hedeflenmektedir. Bankacılık sektörünün içinde bulunduğu koşullara göre her iki yaklaşımın da yararlı ve zararlı yönleri bulunmaktadır (Özince, 2002: 83).

Bankacılık sektörünün sahip olduğu koşullar dikkate alınarak yeniden yapılandırmada uygulanabilecek çeşitli yöntemler bulunmaktadır. Bu yöntemler sermaye artışı veya kar artışı suretiyle sermayenin güçlendirilmesi; yeni ortaklar alınması veya mevcut ortaklık yapısında değişiklik yapılması suretiyle banka ortaklık yapısının güçlendirilmesi; yoğunlaşmanın azaltılması gibi yöntemlerle sektördeki rekabet yapısının iyileştirilmesi; belirli şartlar dâhilinde likidite ve/veya sermaye desteği şeklinde kamu desteği sağlanması; bankaların kamu yönetimi şemsiyesi altına alınması; kamu bankaları için özelleştirme yapılması; kurumsal yönetim ilkelerine uyum ve etkin gözetim ile yönetim kalitesinin artırılması; birleşme, bölünme ve tasfiye yöntemlerinden uygun olanların uygulanması olarak özetlenebilmektedir (Özince, 2002: 83). Yeniden yapılandırma programları açısından önemli bir husus ise söz konusu yöntemler uygulanırken sistemik riskin ortaya çıkarılmamasıdır. Bu gibi durumlarda ise kamu desteği, mevduat sigortası, ek likidite verilmesi gibi uygulamalar gündeme gelmektedir.

Bankacılık sektörünün yeniden yapılandırılmasına ek olarak banka kredilerini büyük kısmını oluşturan şirketlerin finansal durumlarının iyileştirilmesi için de zaman zaman yeniden yapılandırma söz konusu olmaktadır. Böylece, varlı̆̆ını sürdüremeyecek durumda olan şirketlerin çözümlenmesi, varlığını sürdürebilecek durumda olan şirketlerin yeniden yapılandırılması, finansal sektörün güçlendirilmesi ve uzun dönemli ekonomik büyüme için gerekli koşulların sağlanması hedeflenmektedir (Ataman Erdönmez, 2002: 67).

Makroekonomik yapının katkısıyla birlikte TBS'nin odağına oturduğu 2000 ve 2001 krizleri bir yeniden yapılandırma programı uygulanmasını zorunlu kılmıştır. Bu amaçla, 2001 Mayıs ayında Güçlü Ekonomiye Geçiş Programı uygulanmaya başlanmıştır (Ataman Erdönmez, 2003a: 38). Bu kapsamda, 2001 Temmuz'da vergi kanunlarında değişiklik yapılmış ve 2002 Ocak ayında finansal sektöre olan borçların yapılmasına ilişkin kanun yayınlanmış, böylece hem bankaların hem de şirketlerin yapılandırılmasına ilişkin süreç başlatılmıştır (Ataman Erdönmez, 2003b: 49). Ayrıca BDDK tarafından yapılan ikincil düzenlemelerle banka bilançolarındaki takipteki kredilerin satılabilmesinin önünü açmak için varlık yönetim şirketlerinin kuruluşuna ilişkin mevzuat oluşturulmuştur. Ek olarak, 2002 Nisan ayında şirketlerin borçlarının yeniden yapılandırılması için İstanbul Yaklaşımı başlatılmıştır. Bu kapsamda, nitelikleri düzenleme gerekliliklere uyan şirketlerin borçları yapılandırma kapsamına alınmıştır (Ataman Erdönmez, 2002: 75-76-77). Diğer taraftan, 2003 yılında İcra ve İflas Kanunu'nda değişiklikler yapılmıştır (Ataman Erdönmez 2003b: 50).

2008 krizinde ise kredi derecelendirme kuruluşları, değerleme, bilgilendirme ve muhasebe, likidite ve risk yönetimi ile sermaye yeterliliğinin güçlendirilmesi hususları ön plana çıkmıştır (Ataman Erdönmez 2009: 
100). TBS'nin kazanımlarını korumak için uluslararası kriterlere göre sağlanması gereken \%8 SYR, \%12 olarak sürdürülmeye devam edilmiştir (Taşar, 2009: 32). Tedbirler kapsamında TCMB ihracat reeskont kredisi kullanımını kolaylaştııılıp limit artırılırken yabancı para zorunlu karşılık oranları düşürülmüştür. BDDK ise bankalardan kar dağıtımı yapmamalarını ve karın özkaynaklarda tutulması istemiştir. Böylece, bankalardan yapılandırma talebinde bulunacak finansal olmayan kuruluşlar için kaynak oluşturulmuştur (İslatince, 2018: 162).

Dünyada etkileri ağır bir şekilde hissedilen 2008 küresel krizi dikkate alındığında, 2001 krizinden sonra uygulanan BSYYP'nin TBS açısından genel olarak başarılı olduğunu söylemek mümkündür. Nitekim küresel krizin Türkiye'yi çok fazla etkilememesi söz konusu husus açısından açık bir göstergesidir (Çam ve Özer, 2018: 338).

Diğer taraftan, kriz ve sonrasındaki süreçlerde alınan tedbirlerin olumlu ve olumsuz etkilerinin olacağı unutulmamalıdır. Nitekim mevduat sigortası uygulaması kapsamında mevduatlara verilen tam güvence 1994 krizinin aşılmasına önemli rol oynarken 2000 ve 2001 krizlerinin oluşumunda ise önemli nedenlerden biridir (Çolak, 2001: 16)

\section{Literatür Taraması}

Literatürde Türk bankacılık sektörünün yapılandırılması ile ilgili çeşitli çalışmalar yer almaktadır. Çolak (2001), 2000 ve 2001 krizleri sürecinde Türkiye Cumhuriyet Merkez Bankası (TCMB)'nin "son kredi merci" fonksiyonunu yerine getirmediği için kriz nedeniyle ortaya çıan maliyetin arttığını ve TBS'nin yapılandırılmasına yönelik BDDK'nın yaptığı ikincil düzenlemelerin bankacılık sisteminde etkinliği artırmak yerine cezalandırmaya odaklandığı için kırılganlığı artırdığı sonucuna ulaşmıştır. Uygur (2001), finansal kesimin yapılandırılmasını da kapsayan istikrar programının başarıya ulaşabilmesi için Uluslararası Para Fonu (IMF) ile yapılacak bir program dâhilinde yürütülmesi gerektiğini ifade etmiştir. Ataman Erdönmez (2002), yeniden yapılandırma programlarının başarıya ulaşabilmesi için finansal sistemin güçlendirilmesini temel bir gereklilik olarak tanımlamış, bunun yanı sıra farklı çıkar grupları arasındaki çatışmaların giderilmesinde, piyasada meydana gelen aksaklıkların düzeltilmesinde ve krizin ekonomik ve sosyal maliyetinin hafifletilmesinde devletin öncü rol oynaması gerektiğini belirtmiştir. Özince (2002) ise bankacılıkta yeniden yapılandırmanın başlıca unsurlarını sermayenin güçlendirilmesi, risk yönetim sürecinin değiştirilmesi, sorunlu aktiflerin azaltılması, iyi yönetişim ve düzenleme ve denetim sisteminin iyileştirilmesi olarak ifade etmiştir.

Acar Boyacıŏ̆lu (2003), krizlerin ardından TBS'nin gelişimi için sektörün temel faaliyetlerine odaklanması; sermaye artışı, yeni hissedarlar bulunması, birleşme ve satın alma gibi yöntemlerle finansal yapılarının güçlendirilmesi; varlık, yükümlülük ve risk yönetimi uygulamalarının gözden geçirilmesi şeklindeki önerilerini sunmuştur. Ataman Erdönmez (2003a), bankaların yanı sıra 2002 yılında yürürlüğe konulan Finansal Yeniden Yapılandırma Programı ile bir taraftan şirketlerin yapılandırılması diğer taraftan ise bu şirketlerin ekonomiye kazandırılmasının sağlandığını ifade etmiştir. Ataman Erdönmez (2003b), tarihin en derin krizini 2001 Şubat'inda yaşayan Türkiye'de, finansal kesimin yanı sıra reel sektörde de yeniden yapılandırma ihtiyacının ortaya çıktığı belirlenmiştir.

Yıldırım (2004), 2000 ve 2001 krizlerinin TBS'de acil bir yeniden yapılandırma programını gerekli kıldığı ve programın başarısında önemli hususlardan birisinin uygun ve etkin bir düzenleme ve denetleme sisteminin oluşturulması olduğu sonucuna ulaşmıştır. Aydoğan, Aktaş ve Pekkaya (2005), 2001 krizi sonrasında TBS'de yapısal yeniden yapılanmanın henüz başlangıç aşamasında olduğunu, operasyonel yapılanma alanında hala yapılması gerekenlerin bulunduğunu, finansal yapılanma çalışmalarının ise tamamlandığını ifade etmişlerdir. Öncü ve Aktaş (2007), yeniden yapılandırma döneminde kamu bankalarının, özel ve yabancı bankaların verimlilik oranlarındaki artışın birbirine oldukça yakın olduğu sonucuna ulaşmışlardır.

Bumin (2009), 2001 yılında gerçekleştirilen BSYYP programı sonrasında 2002-2008 döneminde TBS'nin iyileşme gösterdiği, TBS'de 2002-2007 döneminde karlılık performansında artış yaşandı̆̆ı̆, ancak 2008 küresel krizinin etkilerinin hissedilmeye başlanmasıyla birlikte karlılık performansında düşüş yaşandığı sonuçlarına ulaşmıştır. Bumin ve Cengiz (2009), Pamukbank'ın devri sonucunda Halk Bankası'nın etkinliğinde artış yaşandığını belirlemişlerdir. Taşar (2009) 2001 sonrasında TBS'nin yapılandırılmasına yönelik olarak bağımsız düzenleyici ve denetleyici kurumların oluşturulmasının ve bu kurumlar eliyle gerçekleştirilen düzenleme ve denetim faaliyetlerinin, TBS'nin 2008 küresel krizinden etkilenmeyecek kadar sağlam bir yapısal özellik kazanmasını sağladığı sonucuna ulaşmıştır. Çolak (2012) ise diğer etkenlerin yanı 
sıra Hazine'nin ve BDDK'nın izlediği iktisadi politikaların ve TBS'ye yönelik uygulamaların, etkin ve şeffaf bir denetim yapısının oluşturulmamasına neden olduğu, böylece 2001 krizinin yaşanmasında temel sebepler olduğu sonucuna ulaşmıştır.

Bumin (2016), BSYYP'nin uygulanmasıyla birlikte 2004-2014 döneminde TBS'nin bilançosunda yapısal değişimler gerçekleştiği, bankaların menkul kıymet ve faiz kaynaklı gelirler yerine aracılık fonksiyonlarına odaklandığı, kredilerin aktifler içindeki payının arttığı, mevduatların temel fonlama kaynağı olmaya devam ettiği, bankaların SYR'lerinin yasal sınırların oldukça üzerinde gerçekleştiği, TBS'nin verimlilik, işletme ve performans rasyolarında iyileşmenin ortaya çıktığı sonuçlarına ulaşmıştır. Gülen Alpay ve Sakınç (2017), krizlerden önceki 1990-2000 dönemi ile krizlerden sonraki 2002-2012 döneminde bankaların performanslarını ele alınarak uygulanan BSYYP'nin etkinliğini ölçmeyi amaçlamışlardır. 2001 sonrasında TMSF'ye devredilmeyip TBS'de faaliyete devam eden bankaların faaliyetlerini daha kaliteli bir şekilde sürdürdüğünü, 2001 krizi sonrası bankacılık sektöründeki yeniden yapılandırmanın amacına ulaştığını ve sektöre ciddi boyutta katkı sağladığını, 2008 krizinin Türkiye'de derin etkiler oluşturmamasının aynı zamanda bu durumun bir doğrulaması ve yansıması olduğunu ortaya koymuşlardır.

Arabacı (2018), 2001 krizi sonrasında 2002-2007 döneminin TBS için bir yeniden yapılandırılma dönemi olduğunu ve alınan tedbirlerin olumlu sonuçlarının 2004 yılından itibaren görülmeye başlandığını ifade etmiştir. İslatince (2018) ise oldukça zorlayıcı etkileri ve ağır maliyetleri olan BSYYP'nin TBS üzerinde olumlu etkiler oluşturduğu sonucuna ulaşmıştır.

Diğer taraftan, literatürde bankacılık sektörünün bilanço kalemlerindeki gelişimi ele çalı̧malar da bulunmaktadır. Oğuz (2006), 2005-2013 dönemini incelemiş ve TBS'de kamu sermayeli mevduat bankalarının aktif büyüklüğünün azaldığını, özel sermayeli kamu bankaları ile katılım bankalarının ise aktif büyüklüğünün arttığını belirlemiştir. Ayrıca, bankaların şube sayılarında artış ve şube başına düşen ortalama personel sayısında düşüş belirlenmiştir.

Tanınmış Yücememiş ve Arıcan (2017), 2009 küresel krizi sonrasında TBS'deki gelişmeleri ele almış ve TBS'nin gelişimini sürdürdüğünü, kriz sonrasında başarılı bir performans sergilediğini ve ekonomik faaliyetlerin fonlanmasına katkı sağlamaya devam ettiğini belirlemişlerdir. Ayrıca, 2016 yılındaki belirsizliklerden dolayı oynaklığın yüksek bir yıl olduğu, buna rağmen TBS'nin güçlü yapısını sürdürdüğü ifade edilmiştir.

Literatürde yer alan çalışmalar değerlendirildiğinde, TBS'de sektörün yapılandırılmasına ve bu çalışmaların etkilerine yönelik olarak 2019 yılında hazırlanan bir çalışma bulunmadığı, 2019 öncesinde yayınlanan çalışmalarda ise krizlerin maliyetleri, düzenlemeler ve göz önünde bulundurulması gereken temel hususlar açısından sektörün yapılandırılma çalışmalarının ele alındığı görülmektedir. Bu çalışma ise 2000, 2001 ve 2008 krizleri sonrasında alınan yapılandırma önlemlerinin etkileriyle birlikte 2018 yılsonu itibarıyla çeşitli bileşenler açısından sektörün geldiği noktanın ele alınması amaçlanmıştır. Bu kapsamda, 2003-2019/10 dönemi ele alınmıştır.

\section{Yapılandırma Çalışmalarının Türk Bankacılık Sektörünün Gelişimi Üzerindeki Etkileri}

Bu bölümde, Türkiye'de gerçekleştirilen yapılandırma çalışmalarının TBS'nin gelişimi üzerindeki etkilerini incelemek amacıyla 2003-2019/10 dönemine ilişkin veriler kullanılmıştır. İlk kısımda TBS'nin güncel yapısına değinildikten sonra ikinci kısımda TBS'nin makro göstergelerindeki gelişmeler, üçüncü kısımda ise TBS'nin finansal sağlamlık göstergeleri incelenmiştir.

\subsection{Sektörün Güncel Yapısı}

2000 ve 2001 krizlerinde bazı bankalarının faaliyet izinlerinin kaldırılması, bazı bankaların iradi tasfiyesi ve bazı bankaların birleşmesi gibi faktörlerin de katkısıyla birlikte, Türkiye' de faaliyet gösteren banka sayısında önemli bir düşüş yaşanmıştır (Çetin, 2018: 18). 2003 ve sonrasında ekonomik istikrarın tesis edilmesiyle birlikte Ziraat Katılım, Vakıf Katılım ve Emlak Katılım bankaları gibi bazı bankaların kurulmasına izin verilmiştir. Son olarak 2019 yılında Golden Global Yatırım Bankası BDDK'dan kuruluş izni almış olup faaliyet izni alma süreci devam etmektedir.

Henüz faaliyete geçmemiş olması nedeniyle Golden Global Yatırım Bankası hariç tutulduğunda, güncel durumda Türkiye'de faaliyette bulunan 53 banka bulunmaktadır. Faaliyetteki bankaların çoğunluğu (32 tanesi) mevduat bankacilığı alanında faaliyet göstermektedir. Ek olarak, 13 tanesi kalkınma ve yatırım 
bankası olarak faaliyet göstermektedir. Ayrıca, faaliyette bulunan 6 tane mevduat bankası bulunmaktadır. Diğer taraftan, 2 banka TMSF bünyesinde faaliyet göstermektedir (BDDK, 2019a).

\subsection{Türk Bankacılık Sektörünün Makro Göstergelerinin Gelişimi}

Bu kısımda sırasıyla toplam aktifler, mevduatlar, krediler, net kar, yoğunlaşma bileşenlerindeki gelişmeler ele alınmıştır.

\subsubsection{Toplam Aktiflerin Gelişimi}

TBS' de 2003-2019/10 döneminde toplam aktiflerin gelişimine Şekil 1'de yer verilmiştir.

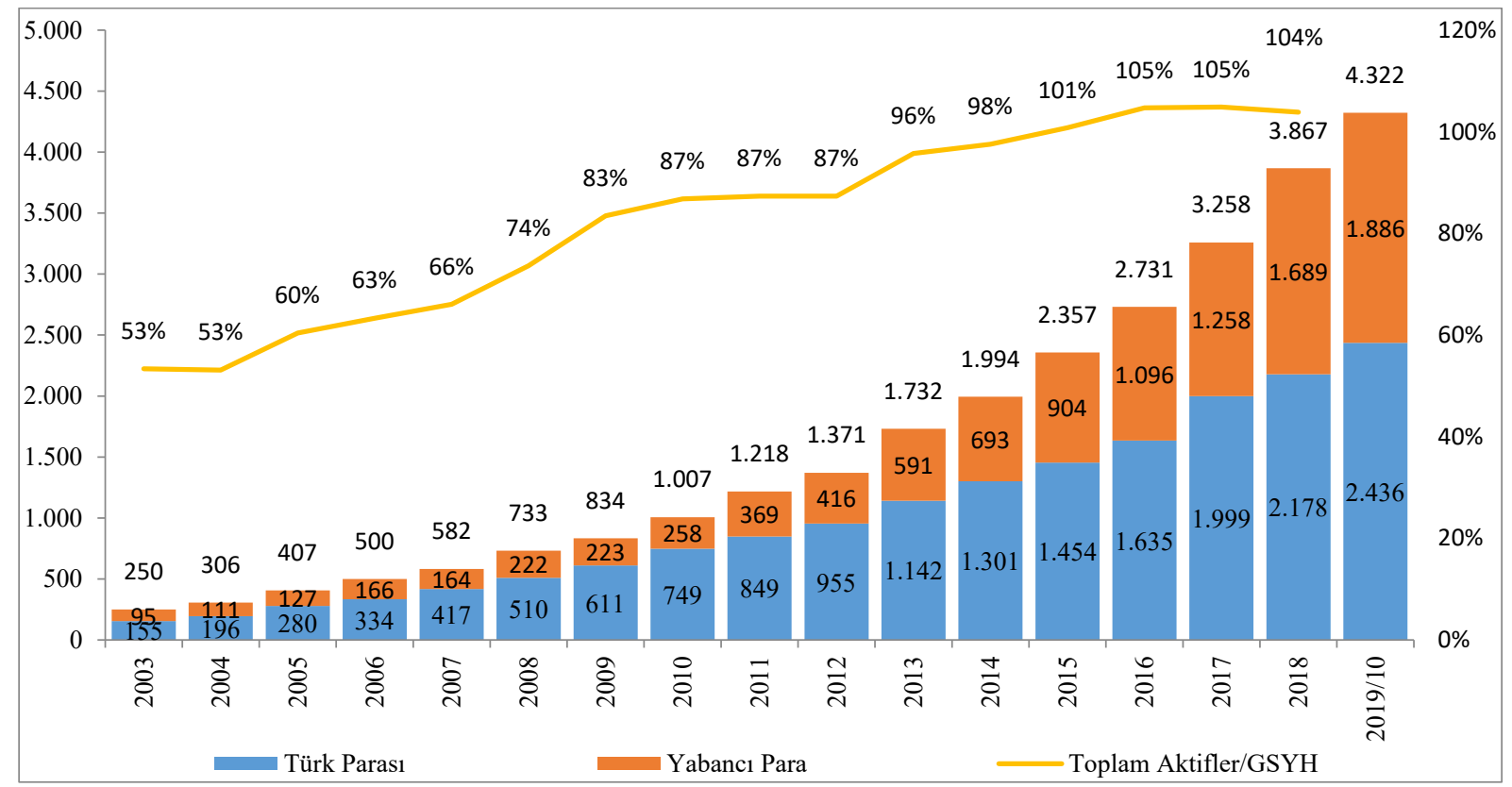

Şekil 1. Toplam Aktiflerin Gelişimi (Milyar TL)

Kaynak: BDDK 2019b, TCMB 2019.

Şekil 1'den görüleceği üzere, TBS'nin 2003 yılında 250 milyar TL olan aktif büyüklüğü yıllar içinde artarak 2007 yılında 582 milyar TL, 2012 yılında 1,37 trilyon TL, 2018 yılında 3,87 trilyon TL, 2019 Ekim itibarıla ise 4,32 trilyon TL seviyesine ulaşmıştır. Diğer taraftan, toplam aktiflerin içindeki Türk Parası (TP)-Yabancı Para (YP) oranı aynı tarihler için sırasıyla $(\% 62, \% 38),(\% 72, \% 28),(\% 70, \% 30),(\% 56, \% 44)$ ve $(\% 56, \% 44)$ şeklinde oluşmuştur. 2017 yılından 2019 Ekim dönemine TP aktiflerde meydana gelen \%6 azalış ve buna mukabil YP aktiflerde görülen \%6 artış, zorlu makroekonomik konjonktürün yaşandığı dönemlerde toplam aktiflerin dolarizasyona uğradığını göstermektedir. Nitekim 2017-2018 döneminde TP ve YP aktiflerde görülen büyüme oranları (\%9, \%34) arasındaki fark bu durumu açık bir şekilde ortaya koymaktadır. 2018

Yıllık Bileşik Büyüme Oranı (YBBO) açısından toplam aktifler incelendiğinde, 2003-2018 döneminde TP aktiflerin \%18, YP aktiflerin \%19,7, toplam aktiflerin ise \%18,7 oranında YBBO kaydettiği görülmektedir.

Ayrıca, toplam aktiflerin Gayri Safi Yurtiçin Hâsıla (GSYH)'ya oranı ele alındığında, 2003 yılında \%53 olan oran yıllar içinde artış göstererek 2007 yılında \%66, 2012 yılında \%87, 2018 yılında \%104 seviyesine ulaşmıştır. Bu oran, TBS'nin toplam aktiflerinin Türkiye'nin GSYH'nden daha yüksek bir tutara ulaştığını ifade etmektedir. Ayrıca, toplam aktifler/GSYH oranında 2003-2018 döneminde \%4,3 YBBO artışı gerçekleşmiştir. 


\subsubsection{Kredilerin Gelişimi}

TBS'de 2003-2019/10 döneminde kredilerin gelişimine Şekil 2'de yer verilmiştir.

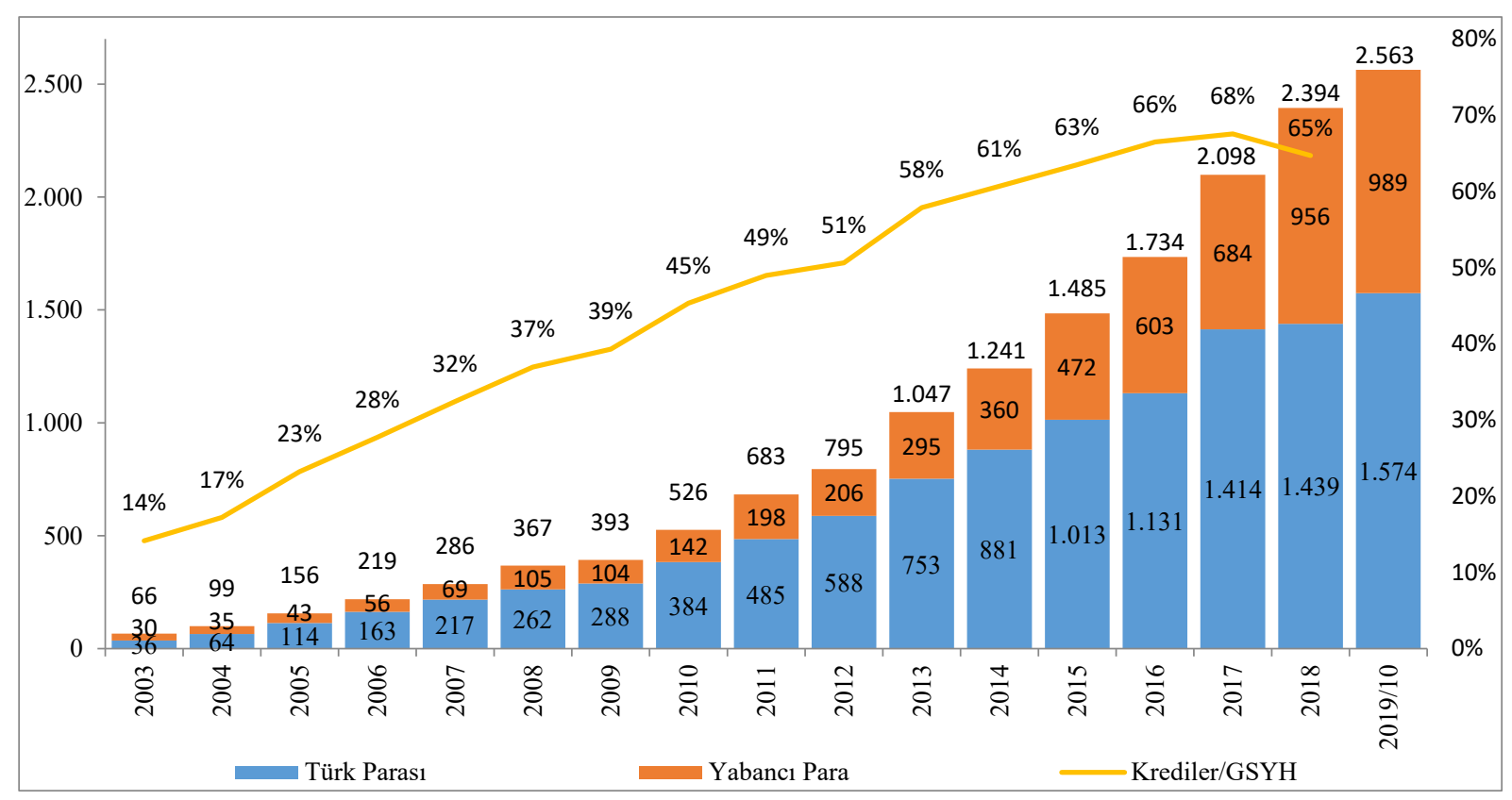

Şekil 2. Kredilerin Gelişimi (Milyar TL) Kaynak: BDDK 2019b.

Şekil 2'den görüleceği üzere, TBS'nin 2003 yılında 66 milyar TL olan aktif büyüklüğü yıllar içinde artarak 2007 yılında 286 milyar TL, 2012 yılında 795 milyar TL, 2018 yılında 2,4 trilyon TL, 2019 Ekim itibarıla ise 2,56 trilyon TL seviyesine ulaşmıştır. Diğer taraftan, kredilerin içindeki TP-YP oranı aynı tarihler için sirasiyla (\%55,\%45), $(\% 76, \% 24),(\% 74, \% 26),(\% 60, \% 40)$ ve $(\% 61, \% 39)$ şeklinde oluşmuştur. 2017 yilından 2019 Ekim dönemine TP kredilerde meydana gelen \%6 azalış ve buna mukabil YP mevduatlarda görülen \%6 artış, büyük oranda zorlu makroekonomik şartlar nedeniyle artan döviz kurlarındaki yükselişten kaynaklanmaktadır. Nitekim 2017-2018 yıllarında TP ve YP kredilerde görülen büyüme oranları (\%2, \%40) arasındaki fark bu durumun en açık göstergelerden biridir.

YBBO açısından krediler incelendiğinde, 2003-2018 döneminde TP kredilerin \%25,9, YP kredilerin \%24,1, toplam kredilerin ise \%25,1 büyüdüğü görülmektedir.

Ayrıca, krediler/GSYH oranı ele alındığında, 2003 yılında \%14 olan oran yıllar içinde artış göstererek 2007 yılında \%32, 2012 yılında \%51, 2018 yılında ise \%65 seviyesine ulaşmıştır. Türkiye'nin GSYH büyüklügüünün 2018 yılsonunda 3,72 trilyon TL'ye ulaştığı dikkate alındığında, kredi/GSYH oranındaki artışın ekonomik büyümeye sağladığı katkı daha iyi görülmektedir. Ayrıca, kredi/GSYH oranında 2003-2018 döneminde \%10 YBBO artışı kaydedilmiştir. 


\subsubsection{Mevduatların Gelişimi}

TBS'de 2003-2019/10 döneminde mevduatların gelişimine Şekil 3'de yer verilmiştir.

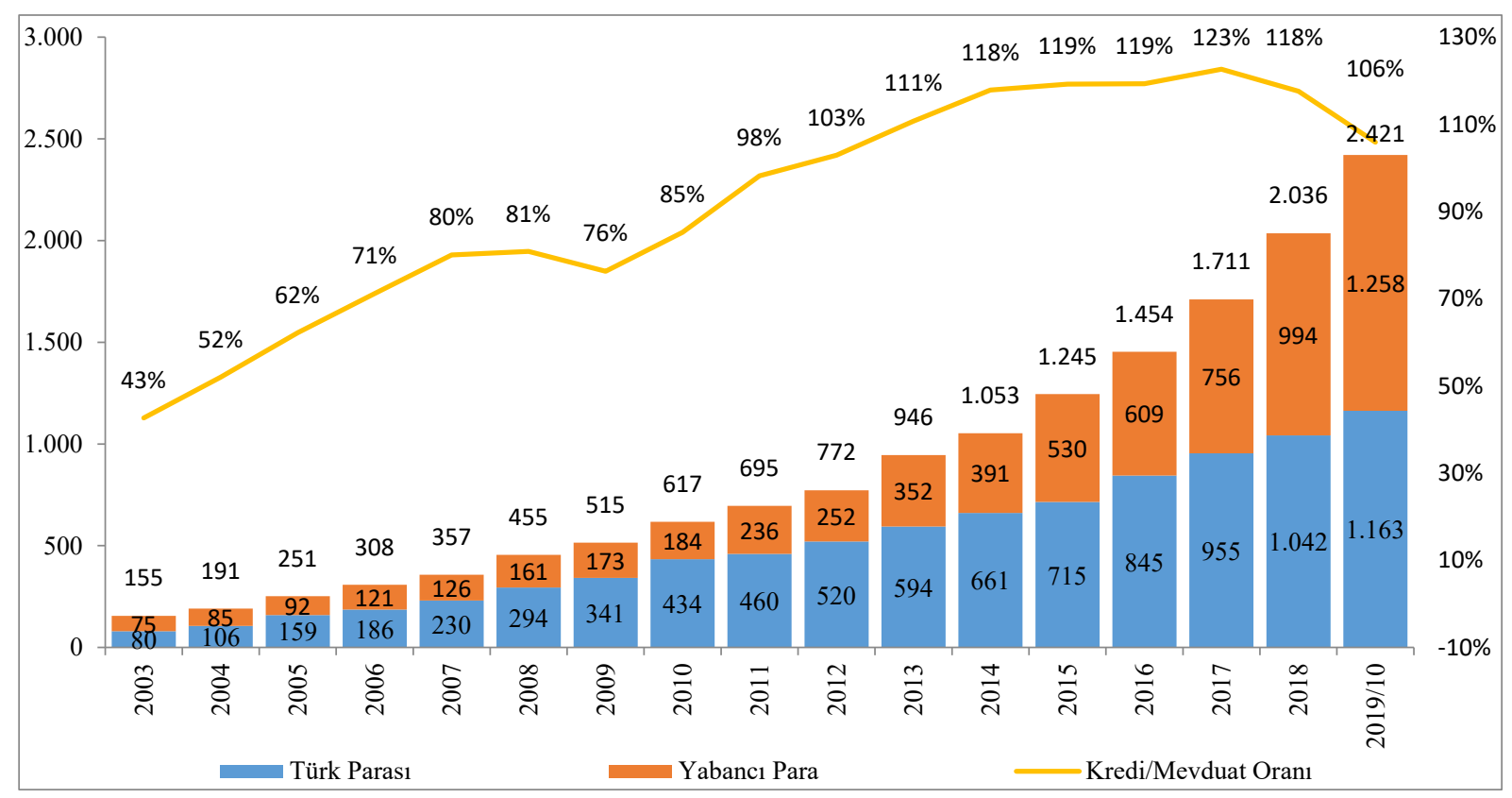

Şekil 3. Mevduatların Gelişimi (Milyar TL) Kaynak: BDDK 2019b.

Şekil 3'den görüleceği üzere, TBS'nin 2003 yılında 155 milyar TL olan aktif büyüklüğü yıllar içinde istikrarlı bir şekilde artarak 2007 yılında 357 milyar TL, 2012 yılında 772 milyar TL, 2018 yılında 2,04 trilyon TL, 2019 Ekim itibarıyla ise 2,42 trilyon TL seviyesine ulaşmıştır. Diğer taraftan, mevduatların içindeki TP-YP oranı aynı tarihler için sırasıyla $(\% 51, \% 49)$, $(\% 65, \% 35)$, (\%67,\%33), (\%51,\%49) ve $(\% 48, \% 52)$ şeklinde oluşmuştur. 2017 yılından 2019 Ekim dönemine TP mevduatlarda meydana gelen \%8 azalış ve buna mukabil YP mevduatlarda görülen \%8 artış, zorlu makroekonomik şartların bulunduğu dönemlerde mevduatların toplam aktiflerden daha hızlı bir şekilde dolarizasyona uğradığını göstermektedir. Nitekim 2017-2018 döneminde TP ve YP aktiflerde görülen büyüme oranları (\%9, \%34) arasındaki fark bu durumu net bir şekilde ortaya koymaktadır. Ayrıca, vurgulanması gereken önemli bir nokta olarak 2019 Ekim döneminde YP mevduatlar TP mevduatların üzerinde bir paya sahiptir.

YBBO açısından mevduatlar incelendiğinde, 2003-2018 döneminde TP mevduatların \%17,4, YP mevduatların $\% 17,5$, toplam mevduatların ise \%17,4 oranında YBBO yakaladığı görülmektedir.

Ayrıca, kredi/mevduat oranı ele alındığında, 2003 yılında \%42,6 olan oran yıllar içinde artış göstererek 2007 yılında \%80, 2012 yılında \%100 bandını aşarak \%102,9, 2018 yılında \%117,6, 2019 Ekim itibarıla ise \%105,9 seviyesine ulaşmıştır. Bu oran, TBS'nin topladığ 1 mevduattan daha fazla tutarda kredi verdiğini göstermektedir. Ayrıca, kredi/mevduat oranında 2003-2018 döneminde \%6,5 YBBO artışı kaydedilmiştir. 


\subsubsection{Net Karın Gelişimi}

TBS'de 2003-2019/10 döneminde net karın gelişimine Şekil 4'de yer verilmiştir.

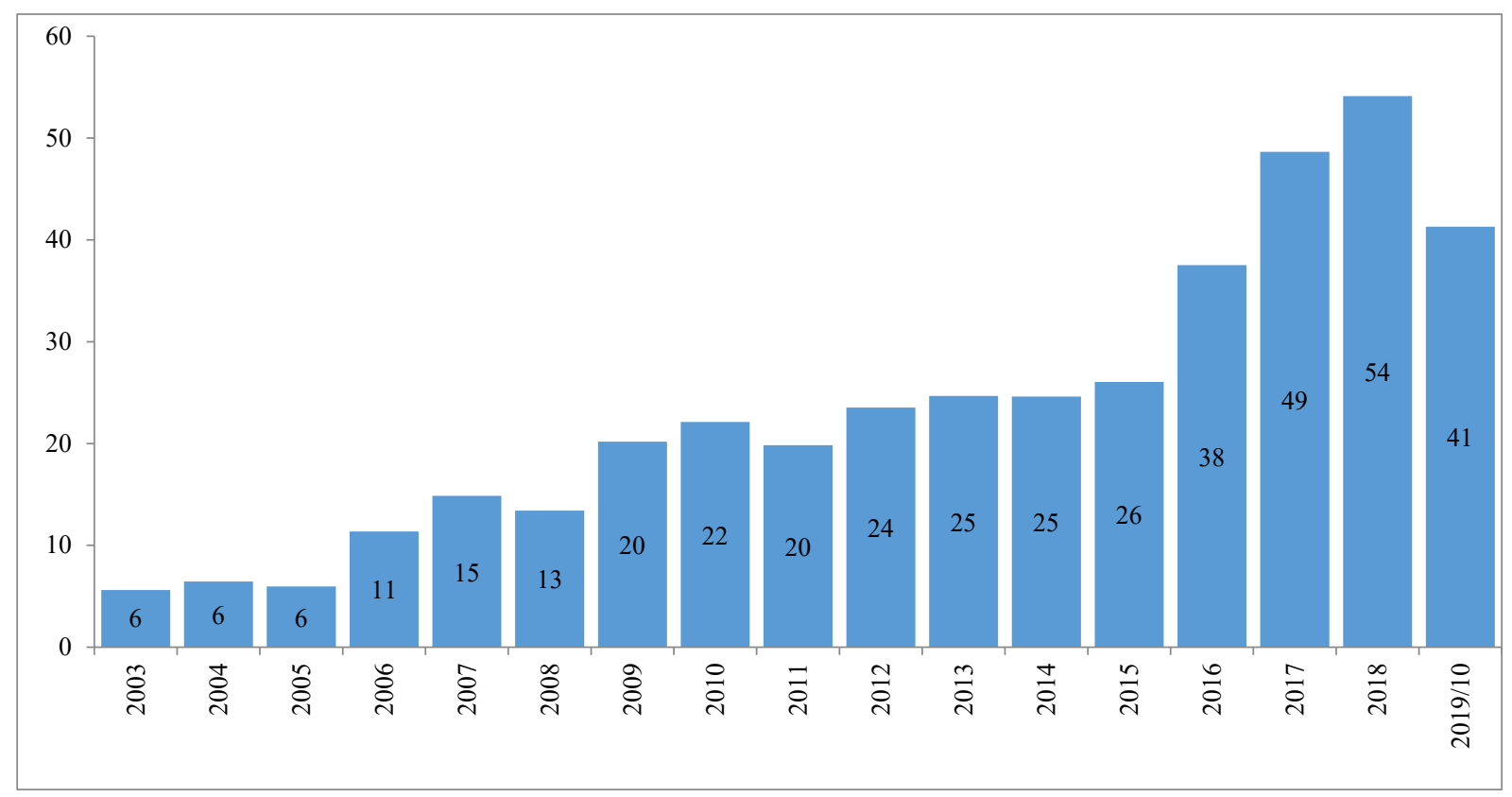

Şekil 4. Net Karın Gelişimi (Milyar TL)Kaynak: BDDK 2019b.

Şekil 4'den görüleceği üzere, TBS'nin 2003 yılında 6 milyar TL olan net karı yıllar içinde artarak 2007 yılında 15 milyar TL, 2012 yılında 24 milyar TL, 2018 yılında 54 milyar TL, 2019 Ekim itibarıla ise 41 milyar TL seviyesine ulaşmıştır. 2019 yılında ilk 10 aylık dönemdeki net kar performansının sürdürülmesi halinde 2019 yılında 49,5 milyar TL net kar tutarına ulaşılması beklenmektedir. Bu rakam, 2018 yılı gerçekleşmelerinden bir miktar aşağıda olsa bile hala önemli düzeyde olduğu ve zorlu makroekonomik koşullar karşısında gayet iyi oluğu söylenebilir. Böylece, TBS kredi hacmindeki büyümeyi destekleyecek özkaynak birikimi sağlamayı 2019 yılında da sürdürebilecektir.

Yıllık Bileşik Büyüme Oranı (YBBO) açısından incelendiğinde, net kar 2003-2018 döneminde \%15,2 büyüme göstermiştir.

\subsubsection{Yoğunlaşmanın Gelişimi}

Bu çalışmada, sektör yoğunlaşmasının ölçülmesinde sıklıkla kullanılan birçok yöntem olan HerfindahlHirschman Endeksi (HHE) kullanılmıştır (Evren vd., 2018: 2). HHE yöntemi sektörde faaliyet gösteren bütün oyuncuları dikkate almaktadır. HHE hesaplaması sonucunda, bir sektördeki yoğunlaşma seviyesi aşağıdaki gibi tanımlanmaktadır (Coşkun vd., 2012: 84-85):

$>$ HHE 100'ün altında ise sektör yüksek derecede rekabetçidir,

$>$ HHE 1.500'ün altında ise sektör yoğunlaşmamıştır,

$>$ HHE 1.500-2.500 arasında ise orta seviyede yoğunlaşma bulunmaktadır,

$>$ HHE 2.500'ün üstünde ise sektörde yüksek/gülü bir yoğunlaşma bulunmaktadır.

TBS'deki yoğunlaşma toplam aktifler, krediler, mevduatlar, özkaynaklar ve net kar bileşenleri bazında hesaplanmıştır. Bununla birlikte, katılım bankalarının TBS içindeki \%5 seviyesindeki payı ve bu bankalara ilişkin 2008 öncesi verilerine ulaşmanın zorluğu dikkate alınarak yoğunlaşma hesaplamasından hariç tutulmuşlardır. Bu kapsamda, TBS'de 2018 yılsonu itibarıyla 47 mevduat, kalkınma ve yatırım bankası bulunmaktadır. Önceki yıllarda ise bu rakam daha düşük olup yıllara göre değişiklik göstermektedir.

TBS'de 2003-2018 döneminde yoğunlaşmanın gelişimine Şekil 5'de yer verilmiştir. 


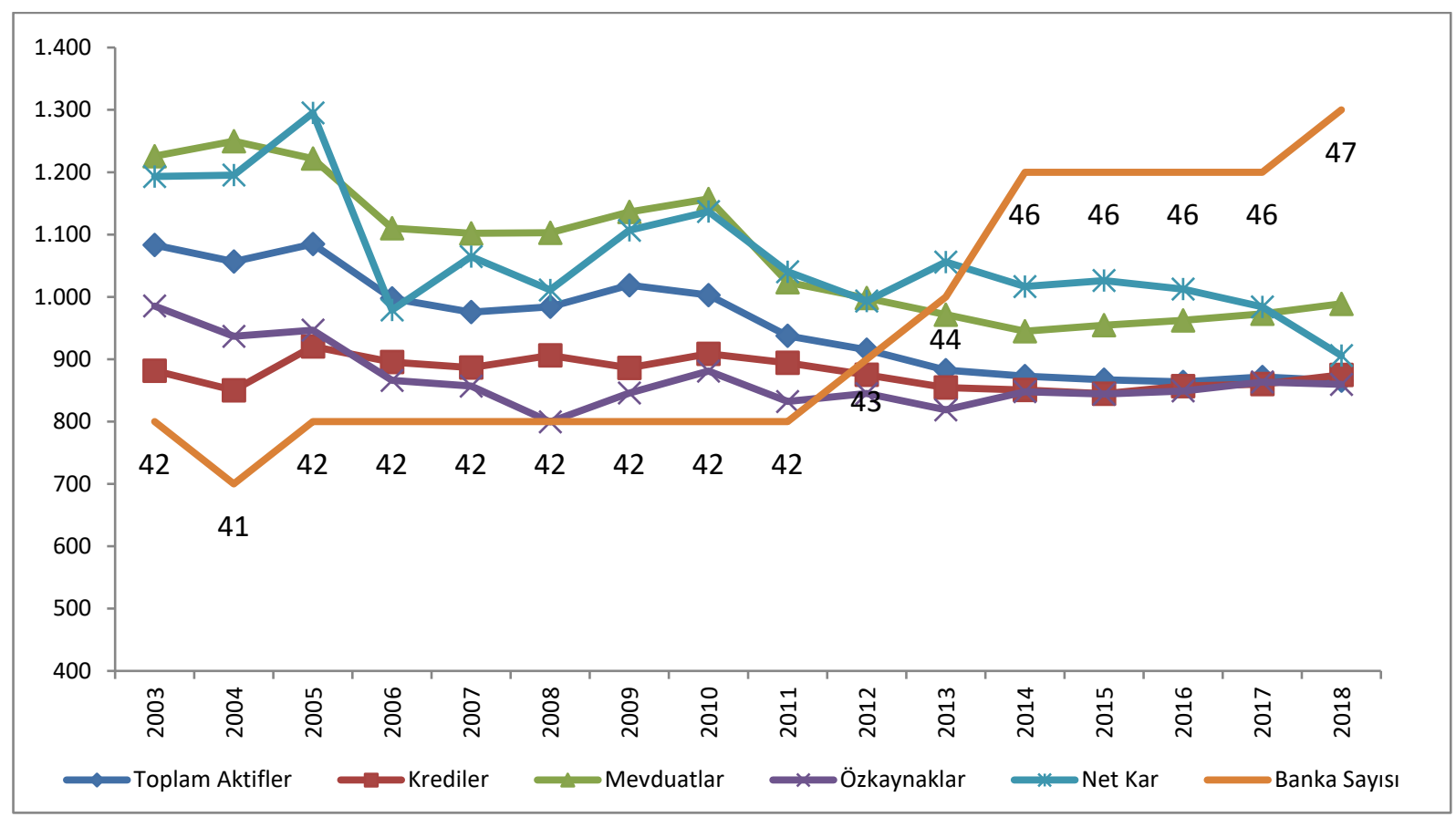

Şekil 5. Yoğunlaşmanın Gelişimi

Kaynak: TBB 2019, TKBB 2019, Yazarın hesaplamaları.

Şekil 5'den görüleceği üzere, TBS toplam aktifler, krediler, mevduatlar, özkaynaklar ve net kar bileşenleri açısından 1.500'ün altında bir değere sahiptir ki bu durum TBS'nin yoğunlaşmamış bir endüstri yapısına sahip olduğunu göstermektedir. HHE değerlerinin 2003-2018 dönemindeki gelişimi incelendiğinde TBS'nin en düşük yoğunlaşmaya kredi bileşeninde sahip olduğu görülmektedir. Ancak 2018 yılında toplam aktifler, krediler ve özkaynaklar bileşenleri bazındaki sektör yoğunlaşması neredeyse aynı seviyededir. Göze çarpan önemli bir husus ise 2008 küresel krizinden sonra 2009 ve 2010 yıllarında yoğunlaşmada görülen artıştır. Yine önemli bir husus ise banka sayısının arttı̆̆ı 2012-2014 döneminde yoğunlaşmada düşüş yaşanmasıdır. TBS toplam aktifler, krediler, mevduatlar, özkaynaklar ve net kar bileşenlerinin hiçbiri bazında tam rekabetçi konumda olmadığı dikkate alındığında, sektöre girişlerin kolaylaştırılması ve böylece yeni girişlerin yaşanmasıyla birlikte sektördeki yoğunlaşmanın daha da azalması ve tam rekabetçi bir yapıya kavuşması mümkün olacaktır.

\subsection{Türk Bankacılık Sektörünün Finansal Sağlamlık Göstergelerinin Gelişimi}

Literatürdeki yayınlar incelendiğinde TBS için farklı finansal sağlamlık göstergelerinin kullanıldığı görülmektedir. Örneğin, Taşkın (2015) aktif kalitesi, likidite, karlılık ve sermaye yeterliliğini ele almıştır. Koç ve Karahan (2017) ise finansal sağlamlık açısından SYR'yi incelemiş ve aktif karlılığı, likidite, aktif kalitesi gibi göstergelerin finansal sağlamlık üzerindeki etkisini araştırmıştır. Bu kapsamda, finansal sağlamlık göstergelerinin gelişimi açısından sırasıyla karlılık, SYR, likidite, yabancı para net genel pozisyonu ve takipteki krediler bileşenlerindeki gelişmeler ele alınmıştır. 


\subsubsection{Karlılığın Gelişimi}

TBS' de 2003-2019/10 döneminde özkaynak ve aktif karlılığının gelişimine Şekil 6' da yer verilmiştir.

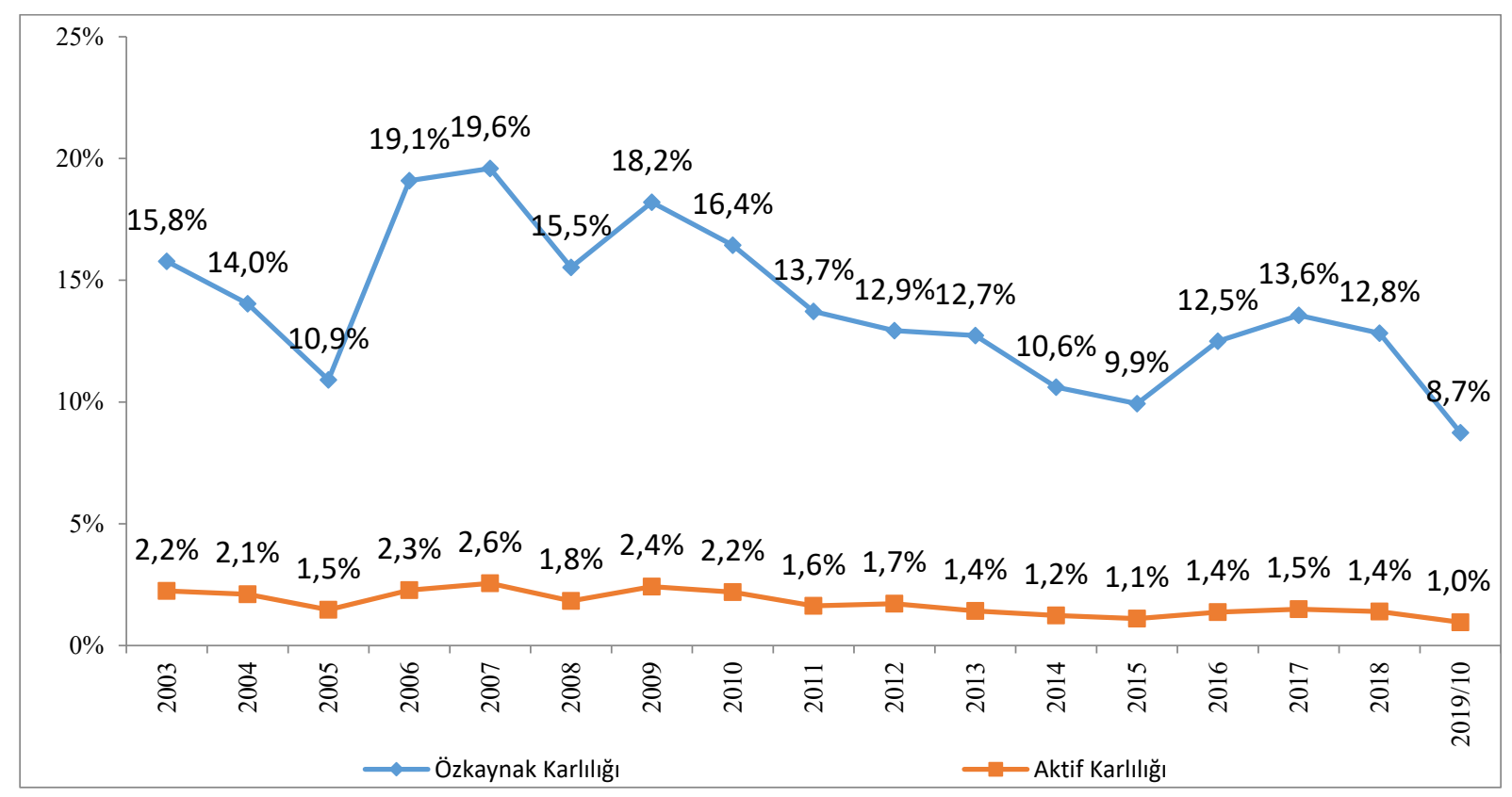

Şekil 6. Özkaynak ve Aktif Karlılığının Gelişimi (Milyar TL)

Kaynak: BDDK 2019b.

Şekil 6'dan görüleceği üzere, TBS'nin 2003 yılında \%15,8 olan özkaynak karlılığ1 yıllar içinde dalgalanma göstererek 2007 yllında \%19,6, 2012 yılında \%12,9, 2018 yılında \%12,8, 2019 Ekim itibarıyla ise \%8,7 seviyesinde gerçekleşmiştir. 2019 ilk 10 aylık dönemdeki net kar performansının sürdürülmesi halinde 2019 yılında 49,5 milyar TL net kar ve \%10,5 özkaynak karlılı̆ına ulaşılması beklenmektedir. Bu rakamlar, 2018 yılı gerçekleşmelerinden bir miktar aşağıda olsa bile hala önemli düzeyde olduğu ve zorlu makroekonomik koşullar karşısında gayet iyi oluğu söylenebilir. Böylece, TBS kredi hacmindeki büyümeyi destekleyecek özkaynak birikimi ve özkaynak karlılığı sağlamayı 2019 yılında da sürdürmüş olacaktır.

Diğer taraftan, TBS'nin 2003 yılında \%2,2 olan özkaynak karlılığı yıllar içinde dalgalanma göstererek 2007 yılında \%2,6, 2012 yılında \%1,7, 2018 yılında \%1,4, 2019 Ekim itibarıyla ise \%1 seviyesinde gerçekleşmiştir. 2019 ilk 10 aylık dönemdeki net kar performansının sürdürülmesi halinde 2019 yılında 49,5 milyar TL net kar ve \%1 aktif karlılığına ulaşılması beklenmektedir. Bu rakamlar, 2018 yılı gerçekleşmelerinden bir miktar aşağıda olsa bile hala önemli düzeyde olduğu ve zorlu makroekonomik koşullar karşısında gayet iyi oluğu söylenebilir.

Yıllık Bileşik Büyüme Oranı (YBBO) açısından incelendiğinde, 2003-2018 döneminde özkaynak karlılığı \%1,3, aktif karlılı̆̆ 1 ise $\%-2,9$ büyüme göstermiştir. 


\subsubsection{Sermaye Yeterliliği Rasyosunun Gelişimi}

TBS' de 2003-2019/10 döneminde SYR'nin gelişimine Şekil 7'de yer verilmiştir.

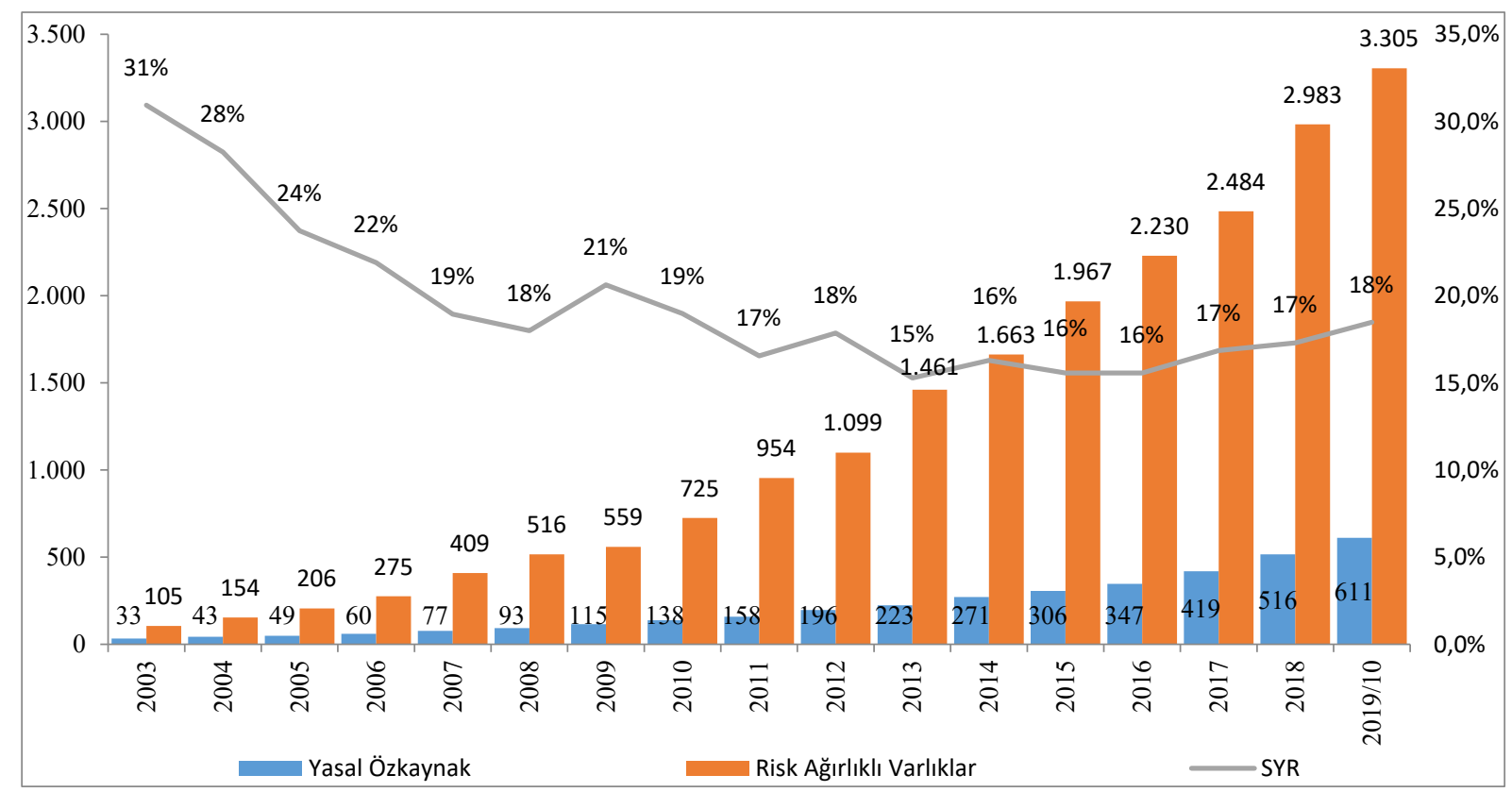

Şekil 7. SYR Gelişimi (Milyar TL) Kaynak: BDDK 2019b.

Şekil 7'den görüleceği üzere, TBS'nin 2003 yılında \%31 olan SYR, risk ağırlıklı varlıklarda yaşanan artış ve bu artışın gerisinde kalan özkaynak artışı nedeniyle yıllar içinde dalgalanma göstererek 2007 yılında \%19, 2012 yılında \%18, 2018 yılında \%17, 2019 Ekim itibarıyla ise \%18 seviyesinde gerçekleşmiştir. Ayrıca, 20032018 döneminde özkaynaklarda \%18,8 YBBO görülürken risk ağırlıklı varlıklarda ise YBBO \%23,2 olmuştur. Dolayısıyla, söz konusu dönemde SYR \%-3,6 YBBO oranında düşüş göstermiştir. Diğer taraftan, BASEL gibi uluslararası standartlarda SYR'nin \%8 olması gerektiği dikkate alındığında, TBS'nin hala oldukça yüksek bir SYR'ye sahip olduğu rahatlıkla görülebilmektedir. Bu husus, önümüzdeki süreçte TBS'nin kredi büyümesini artırmak için yeterli özkaynağı bulunduğunu göstermesi açısından önem taşımaktadır.

\subsubsection{Likiditenin Gelişimi}

TBS'de 2003-2019/10 döneminde likidite yeterlilik oranının farklı vade kırılımlarında gelişimine Şekil 8'de yer verilmiştir.

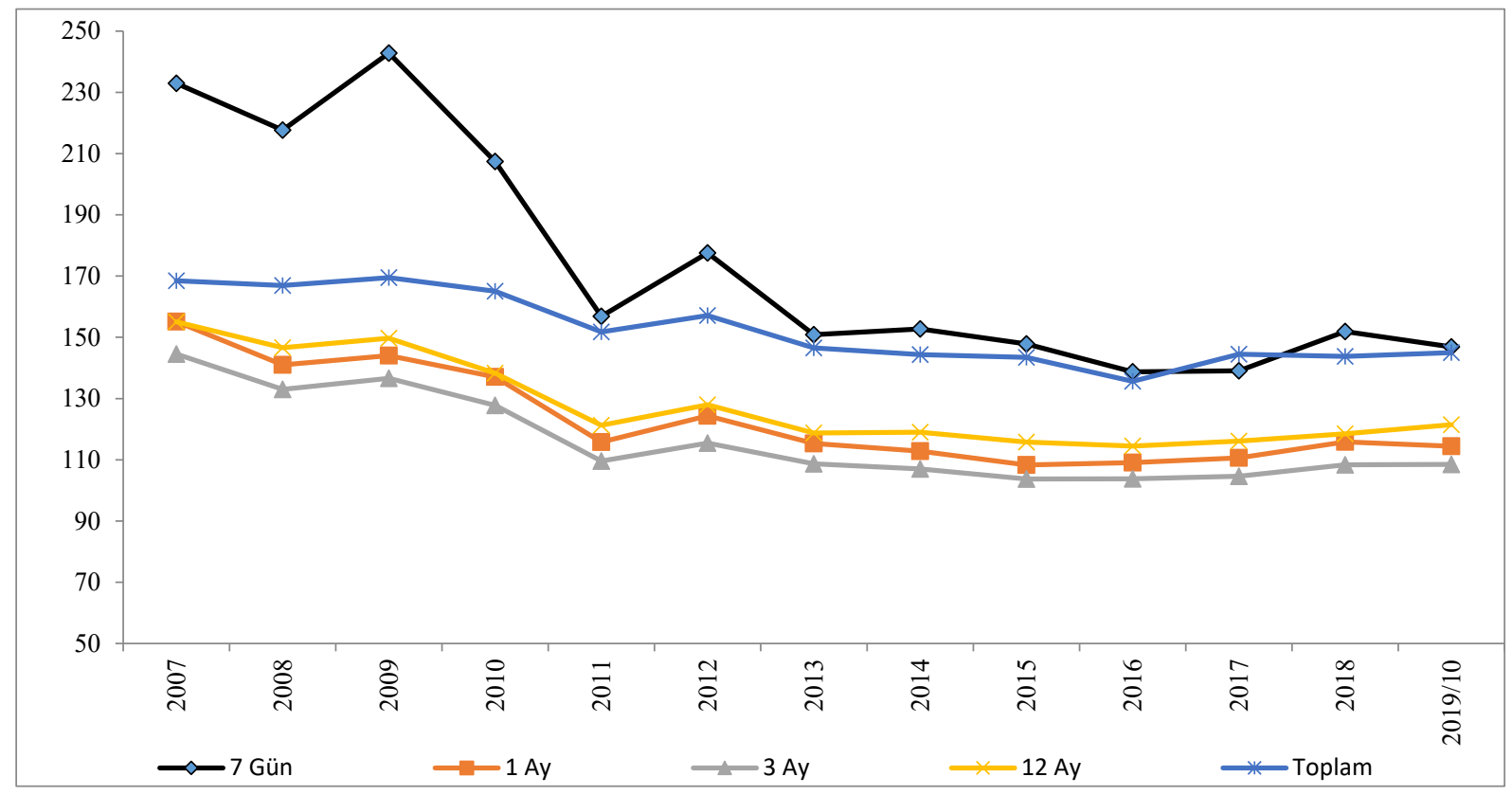

Şekil 8. Likidite Yeterlilik Oranının Gelişimi Kaynak: BDDK 2019b. 
Şekil 8'den görüleceği üzere, TBS tüm vade kırılımlarında ve toplamda $\% 100$ 'ün üzerinde likidite yeterlilik oranına sahiptir. 2007 yılında \%168,5 toplam likidite yeterlilik oranı 2012 yılında \%157,1, 2018 yılında \%143,8, 2019 Ekim itibarıyla ise \%145 seviyesinde gerçekleşmiştir. Ayrıca, likidite yeterlilik oranının diğer vade dilimlerinde de toplama benzer durum bulunmaktadır.

\subsubsection{Yabancı Para Net Genel Pozisyonunun Gelişimi}

TBS' de 2003-2019/10 döneminde YPNGP gelişimine Şekil 9'da yer verilmiştir.

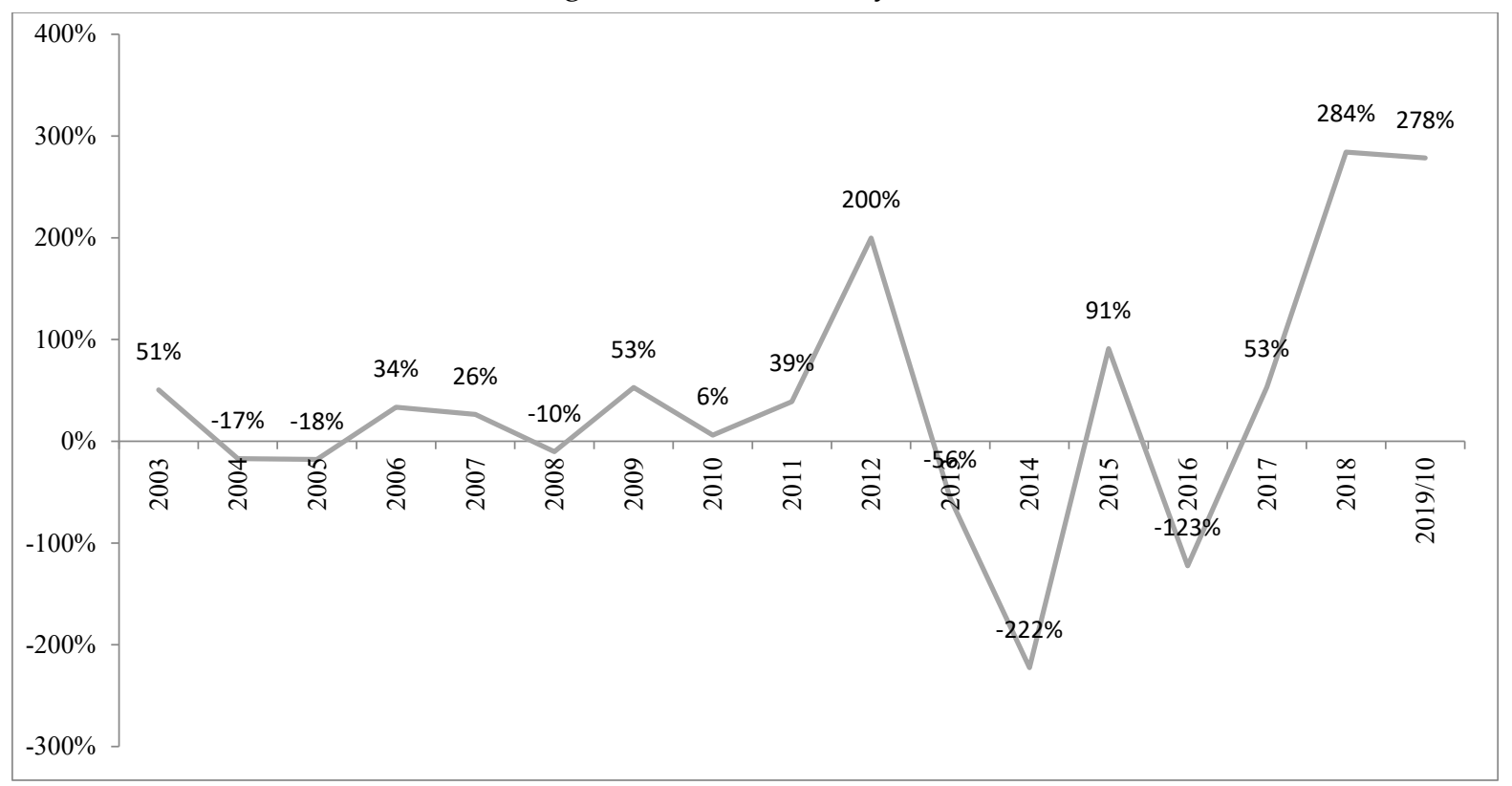

Şekil 9. Yabancı Para Net Genel Pozisyonunun Gelişimi (Milyar TL) Kaynak: BDDK 2019b.

Şekil 9'dan görüleceği üzere, TBS'nin 2003 yılında \%50,6 olan YPNGP/yasal özkaynak standart oranı yıllar içinde ciddi dalgalanma göstererek 2007 \%26,4, 2012 yılında \%199,8, 2018 yılında \%284,2, 2019 Ekim itibarıyla ise \%278,4 olarak gerçekleşmiştir. Diğer taraftan, BDDK tarafından 01.11.2006 tarihinde yapılan düzenlemeye karşın, YPNGP/yasal özkaynak standart oranının 2008 ve 2010 yılları hariç olmak üzere 20072018 dönemindeki bütün yıllarda \%20'lik sınırı aştığı görülmektedir.

Yıllık Bileşik Büyüme Oranı (YBBO) açısından incelendiğinde, YPNGP/yasal özkaynak standart oranı 20032018 döneminde yıllık \%11,4 büyüme göstermiştir.

\subsubsection{Takipteki Kredilerin Gelişimi}

TBS' de 2003-2019/10 döneminde takipteki kredilerin gelişimine Şekil 10' da yer verilmiştir.

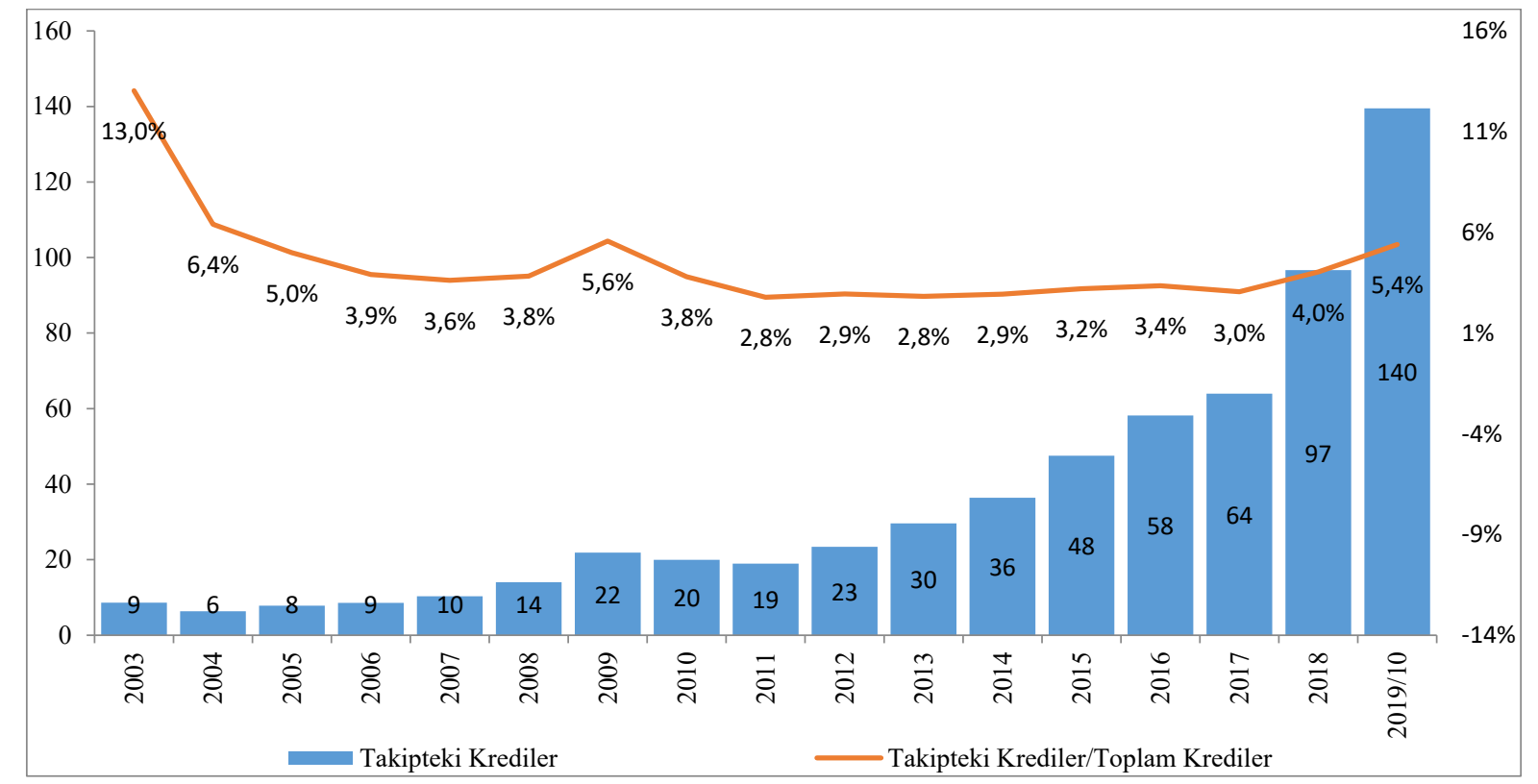

Şekil 10. Takipteki Kredilerin Gelişimi (Brüt, Milyar TL) Kaynak: BDDK 2019b. 
Şekil 10'dan görüleceği üzere, TBS'nin 2003 yılında 9 milyar TL olan takipteki kredileri yıllar içinde artarak 2007 yılında 10 milyar TL, 2012 yılında 23 milyar TL, 2018 yılında 97 milyar TL, 2019 Ekim itibarıla ise 140 milyar TL seviyesine ulaşmıştır. Ayrıca, 2017 yılından 2018 yılına \%51 artış yaşanmıştır. Bu artış içinde zorlu makroekonomik şartların etkisi büyüktür.

Ayrıca, takipteki krediler/toplam krediler oranı ele alındığında, 2003 yılında \%13 olan oran yıllar içinde kademeli düşüş göstererek 2007 yılında \%3,6, 2012 yılında \%2,9, 2017 y1lında ise \%3 seviyesinde oluşmuştur. Bozulan makroekonomik koşulların etkisiyle birlikte 2018 sonunda \%4 oranına yükselen takipteki krediler/krediler oranı 2019 Ekim itibarıyla \%5,4 olarak gerçekleşmiştir. 2003 yılından 2019 Ekim dönemine oransal olarak toplam krediler içinde takipteki kredilerin payı azalmakla birlikte bu azalmada kredi hacmindeki ciddi büyümenin rolü büyüktür. Tutar olarak bakıldığında takipteki kredilerin 2019 ile birlikte 100 milyar TL bandını aştığı görülmektedir. Takipteki kredilerde görülen bu artış, son dönemde TBS'deki bankaları zorlayan hususların başında gelmesine neden olmaktadır.

YBBO açısından krediler incelendiğinde, 2003-2018 döneminde takipteki krediler \%16,3 oranında büyümüştür. Aynı dönemde takipteki krediler/toplam krediler oranı ise \%-7,1 oranında küçülmüştür.

\section{Sonuç}

Türkiye 2000 ve 2001 yıllarında yaşadığı krizlerle tarihinin en ağır krizlerini tecrübe etmiştir. Bunun bir sonucu olarak hem ekonomide hem de bankacılık sektöründe yeniden yapılandırma çalışmaları başlatılmıştır. Büyük kısmı 2004 yılında tamamlanan bu yapılandırma çalışmaları ile Türk Bankacılık Sektörü için yeni bir dönem başlamıştır. Bununla birlikte 2008 yılında patlak veren küresel kriz yeni bir zorlayıcı dönemin başlangıcı olmuştur. Diğer taraftan, 2017 yılından sonra zorlaşan uluslararası ortam ve ulusal makroekonomik koşulların da katkısıyla Türk Bankacılık Sektörü yeni bir meydan okumayla karşı karşıya kalmıştır. Bu çerçevede, yeniden yapılandırmanın bir kerelik ve kriz dönemlerine mahsus olmadığı, bilakis dinamik ve sürekli bir süreç olduğu dikkatlerden kaçırılmamalıdır. Tüm bu süreçte, yeniden yapılandırma çalışmalarının Türk Bankacılık Sektörünün gelişimi üzerindeki etkilerinin incelenmesi amacıyla bu çalışma hazırlanmıştır. Çalışmada 2003-2019/10 döneminde makro göstergelere (toplam aktifler, krediler, mevduatlar, net kar, yoğunlaşma) ve finansal sağlamlık göstergelerine (karlılık, SYR, likidite, yabancı para net genel pozisyonu, takipteki krediler) ilişkin veriler incelenmiştir.

Uygulanan yeniden yapılandırma programları, günümüzde 53 bankanın faaliyette bulunduğu TBS'nin 20032019/10 döneminde makro göstergeleri (toplam aktifler, krediler, mevduatlar, net kar, yoğunlaşma) ve finansal sağlamlık göstergeleri (karlılık, sermaye yeterliliği rasyosu (SYR), likidite, yabancı para net genel pozisyonu, takipteki krediler) üzerinde önemli derecede gelişim sağlanmasına zemin hazırlamıştır. GSYH'yi aşan toplam aktifler ve artan krediler/GSYH oranı gibi hususlar bu durumun birer örneğini oluşturmaktadır. Bununla birlikte, TBS için hala sorunlu hususlar bulunmaktadır. Nitekim kredilerin mevduatlar üzerinde seyretmesi mevduat faizlerini artırıcı ve dolayısıyla kredileri daha maliyetli getirici bir rol oynamaktadır. Ayrıca, 2019 Ekim itibarıyla mevduatların \%50'sinden fazlasının YP cinsinden olması bir taraftan dolarizasyonun bir göstergesi olurken diğer taraftan bankaların ciddi kur riskine maruz kalmasına neden olmaktadır. Bu durum aynı zamanda para ikamesi etkisi oluşturduğu için TCMB'nin para politikası hedefleri ve uygulamaları açısından da zorluk oluşturmaktadır. Yine artan takipteki krediler de önemli bir sorun teşkil etmektedir.

TBS'nin makro ve finansal sağlamlık göstergelerinde 2003-2019/10 döneminde genel olarak iyileşme görülmesine karşın sorunlu bazı alanlar bulunmaktadır. Örneğin, takipteki kredilerdeki artış dikkat çekicidir. Bu husus, 2018 ve sonrasında bozulan makroekonomik konjonktürle birlikte bankaların kredi verme kapasitesini sınırlamaktadır. Aynı zamanda tahsilatlarda yaşanan sorunlar ve artan yapılandırma talepleri bankaların karlılıkları üzerinde baskı oluşturmaktadır. Nitekim 2019 yılında 2018 yılına kıyasla daha düşük bir net kar ve karlılık gerçekleşeceğine yönelik beklenti bu durumun bir yansımasıdır. Ayrıca, oran olarak \%5,4 seviyesine ve tutar olarak 140 milyar TL seviyesine ulaşan takipteki krediler bankaların yanı sıra düzenleyici ve denetleyici otoritelerin de önem atfetmesi ve çözüm için tüm tarafların birlikte çalışmasını gerektiren bir husus olarak ön plana çıkmaktadır. Son zamanlarda, takipteki kredilerin yapılandırılmasına ilişkin çalışmalar, yapılan yönetmelik ve kanun düzenlemeleri, takipteki kredilerin satın alınması için bazı fonların oluşturulması gibi çalışmalar bu kapsamda değerlendirilebilir. Diğer taraftan, mevduatlarda artan dolarizasyon da yine dikkat edilmesi ve önlem geliştirilmesi gereken bir diğer alandır. 
Ek olarak, Türkiye'nin zor bir dönemden geçtiği dikkate alınarak, \%18 seviyesinde olan ve \%8 olarak uygulanan uluslararası standartların çok çok üzerindeki SYR'de \%12 hedef uygulaması kısmen ve kademeli olarak gevşetilerek bankaların hareket alanının genişletilmesi üzerinde düşünülmesi gereken bir alternatif olarak değerlendirilmektedir. Literatürde yer alan çalışmalar ile bu çalışmada ulaşılan bulgular birlikte ele alındığında, ulaşılan bulguların genel olarak benzer ve uyumlu olduğu görülmektedir. Bununla birlikte, bu çalışmada, daha güncel döneme ilişkin incelemelerin ve tespitlerin yer alması literatüre katkı sağlamaktadır.

Uygulanan yapılandırma programları ve alınan tedbirler Türk Bankacılık Sektörünün gelişimi üzerinde genel olarak olumlu etki yapmıştır. Bununla birlikte, 2017 sonrasında bozulmaya başlayan ulusal ve uluslararası makro ortamla birlikte Bankacılık Sektörü günümüzde yeni bir meydan okumayla karşı karşıyadır. Başta takipteki kredilerde artış, takipteki kredilerin yeniden yapılandırılması taleplerinde artış, kredi büyümesinin yavaşlaması, mevduat tabanındaki daralma, kredi/mevduat oranının \%100'ün üzerinde seyretmesi, mevduatlarda dolarizasyon gibi çeşitli göstergelerde görülen bozulmalar, yeni ve kapsamlı bir yapılandırma programı uygulanmasını zorunlu hale getirmektedir. Bu konuda farklı çabaların olduğu kamuoyuna yansımakla birlikte halen Türk Bankacılık Sektörünün önünü açacak, karşılaşılan sorunlara çare olacak, sorunları temelden çözecek ve yeni bir büyüme ve gelişim dönemi başlatacak kapsamlı bir yapılandırma süreci yeniden başlatılmamıştır. Bu amaçla sorunlar daha da büyümeden kapsamlı bir reform süreci başlatılması önem arz etmektedir.

\section{Kaynakça}

Acar Boyacıŏlu, M. (2003). 1980 sonrası Türk bankacılık sektöründeki gelişmeler, krizlerin sektör üzerindeki etkileri ve iyileştirici öneriler, Selçuk Üniversitesi Sosyal Bilimler Enstitüsü Dergisi, (9), 523538.

Altay, N. O. (2002). Türk bankacilık sektöründe füzyon, İktisat İşletme ve Finans Dergisi, 17(195), 71-79.

Arabacı, H. (2018). Türkiye'de bankacılık sektörünün gelişimi (2000-2016), Meriç Uluslararası Sosyal ve Stratejik Araştırmalar Dergisi, 2(3), 25-42.

Arl, A. and Dağtekin, R. (2008). Early warning signals of the 2000/2001 turkish financial crisis, International Journal of Emerging and Transition Economies, 1(8), 191-218.

Ataman Erdönmez, P. (2002). Ekonomik kriz sonrası kurumsal yeniden yapılandırma süreci, Bankacılar Dergisi, (43), 67-81.

Ataman Erdönmez, P. (2003a). Kurumsal yeniden yapılandırma, Bankacılar Dergisi, (44), 23-42.

Ataman Erdönmez, P. (2003b). Türkiye'de 2001 yılındaki mali kriz sonrasında kurumsal sektörde yeniden yapilandırma, Bankacilar Dergisi, (47), 38-55.

Ataman Erdönmez, P. (2009). Küresel kriz ve ülkeler tarafından alınan önlemler kronolojisi, Bankacılar Dergisi, (68), 85-101.

Aydoğan, E., Aktaş, R. ve Pekkaya, S. (2005). 2001 krizi sonrası dönemde makroekonomik gelişmeler ışı̆̆ında Türk bankacılık sisteminin yeniden yapılandırılmasına ilişkin bir değerlendirme, İktisat, İsletme ve Finans Dergisi, 20(237), 17-48.

BDDK. (2019a). Bankalar, https://www.bddk.org.tr/Kuruluslar-Kategori/Bankalar/1, (Erişim tarihi: 21 Temmuz 2019).

BDDK. (2019b). Aylık Bülten, https://www.bddk.org.tr/BultenAylik, (Erişim tarihi: 1 Aralık 2019).

BK. (2005). 5411 sayılı Bankacilık Kanunu, 01.11.2005 tarih ve 25983 sayılı Resmi Gazete.

Bumin, M. (2009). Kamu bankalarının yeniden yapılandırılması ve sonuçları, Bankacılar Dergisi, 20(70), 17-36.

Bumin, M. ve Cengiz, A. (2009). Banka birleşme ve devralmalarının etkinlik üzerine etkisi: Pamukbank'ın Halkbank'a devredilmesi, İktisat, İşletme ve Finans Dergisi, 24(279), 68-96. 
Bumin, M. (2016). Yeniden yapılandırma sonrası 2004-2014 döneminde Türk bankacılık sektörü, Maliye ve Finans Yazıları, (105), 177-222.

Çam, Ü. ve Özer, H. (2018). Türk bankacıllk sektörünün piyasa yapısının rekabet ve yarışılabilirlik açısından analizi: Panzar-Rosse modeli, Cumhuriyet Üniversitesi İktisadi ve İdari Bilimler Dergisi, 19(1), 336-360.

Çetin, A. (2018). Katılım ve Mevduat Bankalarının Piyasa Etkinliğinin Karşılaştırmalı Analizi ve Bir Uygulama, İstanbul, TBB Yayınları, Yayın No: 329.

Çolak, Ö. F. (2001). Finansal kriz ve bankacılık sektöründe yeniden yapılandırma programı üzerine bir eleştiri, Gazi Üniversitesi İktisadi ve İdari Bilimler Fakültesi Dergisi, 3(2), 15-30.

Çolak, Ö. F. (2012). Türk bankacılık sektörünün Şubat 2001 krizi sonrası durumu ve yeniden yapılandırma programı, Türkiye Ekonomi Kurumu Vakfı Tartışma Metni, No: 2012/14.

Coşkun, M. N., Ardor, H. N., Çermikli, A. H., Eruygur, H. O., Öztürk, F., Tokatlıŏlu, İ., Aykaç G. ve Dağlaroğlu, T. (2012). Türkiye'de Bankacılık Sektörü, Piyasa Yapısı, Firma Davranışları ve Rekabet Analizi, İstanbul, $\quad$ TBB $\quad$ Yayınları, $\quad$ Yayın http://www.tbb.org.tr/Dosyalar/userfiles/file/ecg/rekabetKitap.pdf, (Erişim tarihi: 19 Temmuz 2019).

Gülen Alpay, M. ve Sakınç, İ. (2017). Türk bankacılık sektörünün yeniden yapılandırma öncesi ve sonrası Gri ilişkisel analiz ile finansal performans analizi, Ömer Halisdemir Üniversitesi İ̈BF Dergisi, 10(2), 49-61.

İslatince, N. (2018). Türk bankacıllk sektörü açısından riskler ve 2008 küresel kriz sonrası risklerin bankacılık sektörüne etkileri, 6 SCF International Conference on Economic and Social Impacts of Globalization and Liberalization, 155-171.

Kartal, M. T. (2017). Denetim komitelerinin yeterliliği: Türk bankacılık sektöründe bir uygulama. Doktora Tezi. İstanbul, Marmara Üniversitesi.

Kılcı, E. N. (2017). Bankacılık sektörü bilançolarındaki kırılganlıklar ile krizler arasındaki ilişkinin değerlendirilmesi; Türkiye örneği, 2000-01 krizleri, Finans Politik \& Ekonomik Yorumlar, 54(631), 55-64.

Koç, Y. D. ve Karahan, F. (2017). Türk bankacilık sektöründe finansal sağlamlığın belirleyicileri, International Journal of Academic Value Studies, 3(15), 148-153.

Mishkin, F. S. (1999). Lessons from the Tequila Crisis, Journal of Banking \& Finance, (23), 1521-1533.

Oğuz, A. B. (2016). Türkiye kamu, özel sermayeli mevduat ve katılım bankalarının 2005-2013 arasındaki bazı bilanço kalemlerinin karşılaştırılması, Uluslararası Yönetim İktisat ve İşletme Dergisi, 12(29), 225-241.

Öncü, S. ve Aktaş, R. (2007). Yeniden yapılandırma döneminde Türk bankacılık sektöründe verimlilik değişimi, Celal Bayar Üniversitesi İ̈BF Yönetim ve Ekonomi Dergisi 14(1), 247-266.

Özince, E. (2002). Bankacılık sisteminin yeniden yapılandırılmasına bankaların bakış açısı, Bankacılar Dergisi, (42), 82-87.

Serdengeçti, S. (2001). Türkiye Enflasyonu Yenmek Zorunda, ISO Dergisi, (421).

Tanınmış Yücememiş, B. ve Arıcan, E. (2017). Ekonomik gelişmeler ve seçilmiş göstergelerle Türkiye'de bankacılık sektörü, Finans Politik \& Ekonomik Yorumlar, 54(626), 59.

Taşar, M. O. (2009). Finansal regülasyonlar ve küresel kriz sürecinde Türk dünyası bankacılık sistemlerinin yeniden yapılandırılması, Avrasya Etüdleri, 36 (2), 7-46.

Taşkın, F. D. (2014). Türk bankacılık sektöründe finansal istikrar-rekabet ilişkisi, Maliye ve Finans Yazıları, $1(103), 175-204$.

TBB. (2019). Mali Tablolar, https://www.tbb.org.tr/tr/bankacilik/banka-ve-sektor-bilgileri/veri-sorgulamasistemi/mali-tablolar/71, (Erişim tarihi: 21 Temmuz 2019).

TCMB. (2019). Elektronik Veri Dağıtım Sistemi https://evds2.tcmb.gov.tr/index.php?/evds/serieMarket, (Erişim tarihi: 21 Temmuz 2019). 
M. T. Kartal 11/4 (2019) 3172-3189

TKBB. (2019). Mukayeseli Tablolar, http://www.tkbb.org.tr/mukayeseli-tablolar, (Erişim tarihi: 21 Temmuz 2019).

TMSF. (2019). Fona Devredilen Bankalar, https://www.tmsf.org.tr/tr/Tmsf/Cozumleme/fon.devredilen, (Erişim tarihi: 21 Temmuz 2019).

Tunç, H. (2001). Finansal kriz ve Türkiye ekonomisi, İSO Dergisi, (421).

Uygur, E. (2001). Krizden krize Türkiye: 2000 Kasım ve 2001 Şubat krizleri, Türkiye Ekonomi Kurumu Vakfı Tartı̧ma Metni, No: 2001/1.

Yıldırım, O. (2004). Türk Bankacılık Sektöründe Yaşanan Finansal Krizler (1980-2002): (Nedenleri, Sonuçları ve Ekonomik Etkileri), https://sites.google.com/site/paribustr/o yildirim6.doc, (Erişim tarihi: 15 Temmuz 2019). 